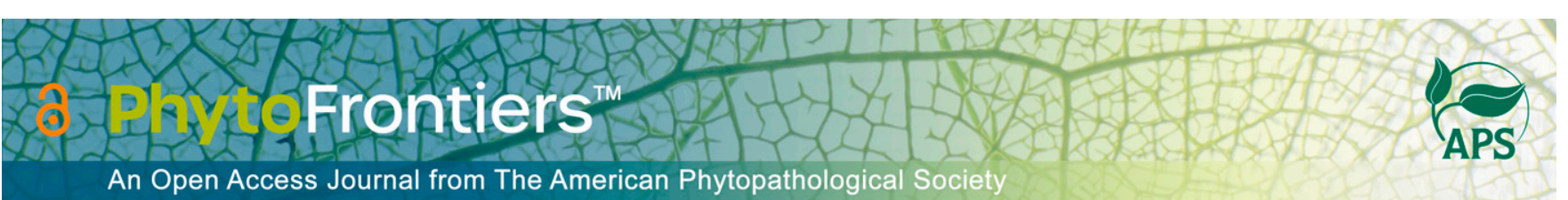

\title{
Research
}

\section{The Use of Aerated Steam as a Heat Treatment for Managing Angular Leaf Spot in Strawberry Nursery Production and Its Effect on Plant Yield}

\author{
William W. Turechek ${ }^{1,+}$ (D) Ole Myhrene ${ }^{2} \mid$ Janet Slovin $^{3}\left(\right.$ ) $\mid$ Natalia A. Peres ${ }^{4}$ (i)
}

${ }^{1}$ U.S. Department of Agriculture, Agricultural Research Service, U.S. Horticultural Research Laboratory, Fort Pierce, FL 34945, U.S.A.

${ }^{2}$ Plantsauna AS, 3410 Sylling, Norway

${ }^{3}$ U.S. Department of Agriculture, Agricultural Research Service, Genetic Improvement of Fruits and Vegetables Laboratory, Beltsville, MD 20705, U.S.A.

${ }^{4}$ University of Florida, Gulf Coast Research and Education Center, Wimauma, FL 33598, U.S.A.

\footnotetext{
${ }^{\dagger}$ Corresponding author: W. W. Turechek; william.turechek@usda.gov
}

Accepted for publication 27 October 2020.

\section{Funding}

This research was partially funded by the National Institute of Food and Agriculture, United States Department of Agriculture, Specialty Crops Research Initiative award number 2014-5118122377 and the United States Department of Agriculture-Current Research Information System No. 6034-22000-039-00D.

Mention of trade names or commercial products in this publication is solely for the purpose of providing specific information and does not imply recommendation or endorsement by the U.S. Department of Agriculture. USDA is an equal opportunity provider and employer.

The author(s) declare no conflict of interest.

\begin{abstract}
Xanthomonas fragariae, the bacterium causing angular leaf spot (ALS) of strawberry, is found routinely on strawberry nursery stock. Although ALS can be a serious disease in production fields, it can be particularly problematic in the sale and trade of commercial nursery stock because of international trade regulations. Heat treatment has been shown to be an effective treatment for managing ALS on nursery stock in small-scale experimental trials. The objective of this research was to design, build, and trial precision thermotherapy units for managing ALS for both research and commercial applications and to test a new thermotherapeutic protocol on strawberry nursery stock that combines a conditioning thermal treatment with an eradicative thermal treatment. Small-plot trials were conducted to evaluate the efficacy of precision thermotherapy on control of ALS using known sources of infected nursery stock. Additionally, trials were conducted in cooperation with commercial nurseries to determine the impact of thermotherapy on plant health and yield and on the natural development of ALS. In the small-plot trials, ALS incidence was significantly lower in plots treated with precision thermotherapy. In the commercial trials, precision thermotherapy had a variable, but negligible, effect on plant growth and yield. ALS, when it occurred, was always lower in thermotherapy-treated plots. Heat is a near-universal biocide. Thus, in addition to managing ALS, the commercial application of precision thermal therapy to strawberry nursery stock may be effective for managing a wide range of pest and disease threats to strawberry while simultaneously reducing pesticide usage.
\end{abstract}

Keywords: Xanthomonas fragariae, Fragaria $\times$ ananassa, Colletotrichum acutatum, Botrytis cinerea, Podosphaera aphanis, thermotherapy, disease management

Thermal or heat treatment has been used for nearly a century as a procedure for managing microbial pathogens and insect pests in plant propagation material (Burr et al. 1989; Buchner 1991; EPPO 2012; Gotoh et al. 2013; Gramaje et al. 2014; Hall et al. 2002; Hoffman et al. 2013; Keck et al. 1995; Kunkel 1936; Lewis Ivey and Miller 2005; Pisetta et al. 2016). Buchner (1991) is credited for publishing the first protocol for 
thermal treatment of strawberry nursery stock, which recommended plants be directly submerged in a hot water bath at 48 to $49^{\circ} \mathrm{C}$ for 5 to $7 \mathrm{~min}$. Although cyclamen mite was the primary target in Buchner's study, the treatment was believed to be effective against other pathogens and insects and thus gained some usage within the nursery industry. It was not immediately evident, however, that this protocol was ineffective at killing Xanthomonas fragariae, the bacterium that causes strawberry angular leaf spot (ALS), and it is believed that this hot water treatment was one of the factors that led to an increase of ALS observed in strawberry production fields in the years following industry adoption of the protocol due to cross-contamination of plants sharing the same bathwater (Herder and Turechek 2006; Turechek and Peres 2009; Turechek et al. 2013). Subsequent research showed that a 5- to 7-min treatment at 48 to $49^{\circ} \mathrm{C}$ is an insufficient thermal treatment for killing $X$. fragariae (Turechek and Peres 2009).

Turechek and Peres (2009) proposed a modified thermal treatment that was effective against $X$. fragariae while simultaneously reducing the risk of pathogen spread between batches. The method, which called for plants to be sealed in plastic bags and then submerged in a hot water bath at $44^{\circ} \mathrm{C}$ for $4 \mathrm{~h}$ or $48^{\circ} \mathrm{C}$ for $2 \mathrm{~h}$, was useful as a "proof of concept" but was not suitable for commercial application. In subsequent work, the use of aerated steam has been investigated as a more efficient method for delivering heat, and a new protocol evolved (Silva et al. 2019; Wang et al. 2017; Zuniga and Peres 2017). The new protocol is a two-step process involving a conditioning treatment consisting of a 1-h exposure to $37^{\circ} \mathrm{C}$ with a 1-h cool-down period at ambient temperature, followed immediately by an eradicative treatment of a 4-h exposure to $44^{\circ} \mathrm{C}$. This protocol has shown great potential for management of ALS and proved very effective at minimizing heat damage to plants in preliminary studies. Parallel geneexpression studies provided evidence that the conditioning treatment conferred increased heat tolerance through the induction of heat-shock proteins and heat stress transcription factors in treated plants (Brown et al. 2016). In addition, the use of aerated steam allowed greater precision during application and is also more easily scalable to large commercial applications. Although the development of this "precision thermotherapy" protocol was motivated by the need for management of $X$. fragariae, preliminary work suggests that it also reduces Colletotrichum acutatum, Botrytis cinerea, Phytophthora spp., and Podosphaera aphanis, as well as two-spotted spider mites (Renkema et al. 2019; Silva et al. 2019; Wang et al. 2017; Zuniga and Peres 2017).

Current management strategies for ALS rely mainly on application of copper compounds to the foliage of established plantings. Copper-based products, however, are generally shortlived, and their repeated use may result in phytotoxicity. More importantly, copper-based compounds mainly act as protectants and are generally ineffective against pathogens that colonize internal tissues. This is the case for $X$. fragariae, which has been shown to survive just below the epidermis, occasionally going systemic (Wang et al. 2018). Antibiotics can be effective against $X$. fragariae; however, none are registered on strawberry for field use. There are some experimental compounds showing promise against $X$. fragariae that may be labeled in the future for use on strawberry (Haack et al. 2019). The main issue is that management of ALS in most commercial operations does not begin until after planting, when plants have been exposed to environmental conditions and horticultural practices that favor dissemination of the pathogen from the initial source plants, such as overhead irrigation used for plant establishment (Gigot et al. 2017).
Strawberry nursery stock is presumed to be the most important source of initial inoculum. However, recent research suggests that the bacteria can survive on a variety of other materials for extended periods of time, although the role of such bacteria in the epidemiology of the disease has not been investigated (Wang and Turechek 2018). We suggest that the application of precision thermotherapy to treat nursery stock prior to planting has many advantages. The most significant is that plants are typically centrally located and neatly arranged for ease in handling and treating. Moreover, the timing of a thermotherapeutic treatment just before planting is sensible because this is likely when the inoculum load is at its lowest level. Despite research demonstrating efficacy of thermal treatment on ALS and potentially other pathogens (Buchner 1991; Turechek and Peres 2009), the industry's greatest concern with respect to thermal treatment is that it will stunt plant growth and reduce plant yield to a degree that negates the benefits of disease control.

The objective of this research was to design, build, and test both a commercial- and a research-scale precision thermotherapy unit (PTU) for their ability to reduce ALS while minimally damaging plants. The commercial-scale unit was tested in cooperation with nurseries who donated plant stock to evaluate the protocol against standard commercial practices. Treated stock was planted and managed on cooperator land to evaluate plant health (a primary concern) and ALS management. Successfully scaling up the process to commercial levels could significantly reduce ALS and its impact on the industry, and likely many other diseases and pests, while substantially reducing pesticide use against a broad range of threats to sustainable production (Turechek et al. 2013).

\section{MATERIALS AND METHODS}

\section{PTU design and construction}

Commercial-scale unit. A walk-in PTU for commercial-scale thermal treatment of dormant strawberry nursery stock was designed by Ole Myhrene and constructed in April 2015 at Lassen Canyon Nursery (LCN) in Redding, CA. The PTU was constructed by retrofitting a used shipping container (outer dimensions [OD] $\sim 6.05 \mathrm{~m}$ length $\times 2.4 \mathrm{~m}$ width $\times 2.4 \mathrm{~m}$ height) (Fig. $1 \mathrm{~A}$ and B) with a 3K24 Amerec Steam Bath Generator (Amerec, Woodenville, WA) composed of a 3K12 master generator and 3G12 slave generator, controlled by a K60 Control Kit (Fig. $1 \mathrm{C}$ and D). Each 12-kW generator could supply $16 \mathrm{~kg}$ of steam per hour at maximum capacity with vapor pressure of $0.5 \mathrm{kPa}$. Two lines of copper piping $(15 \mathrm{~mm}$ outer diameter, $13 \mathrm{~mm}$ interior diameter, cross section of $132.67 \mathrm{~mm}^{2}$ ) — one line per generator-were introduced through access holes into a wooden duct constructed along the length of each side of the container (Fig. 2). The access holes were located at the two lower corners of the back wall of the shipping container, opposite to the mounted generators. Ten ventilation holes were drilled along the length of the copper piping at $60-\mathrm{cm}$ intervals beginning from the first hole, which was located about $40 \mathrm{~cm}$ from the back wall where the copper line entered the container (Fig. 2C). To ensure an even distribution of steam, the diameter of the holes-with the exception of the first hole-increased with distance from the source. From nearest the generator, the diameters were 3, 2.5, 3, $3.5,3.5,4,4,5,6$, and $6 \mathrm{~mm}$, with the sum of their cross-sectional areas being nearly equal to the cross-sectional area of the interior dimensions of the copper supply line. The duct was built by running several $\sim 1.9 \times 14$-cm wooden pine boards along the length of the $\sim 6-\mathrm{m}$ container, standing the boards on their $1.9-\mathrm{cm}$ 
edge, and then fastening smaller wooden boards $(\sim 1.9 \times 14 \times$ $38.8 \mathrm{~cm}$; circled in Fig. 2B) centered above each ventilation hole as baffles to diffuse the steam (Fig. 2A and B). A temperature sensor attached to the control kit was mounted approximately $10 \mathrm{~cm}$ from the floor near the line's entry point to the container (Fig. 3A and B). For additional temperature control, an adjustable wooden damper was installed just above the temperature sensor (Fig. 3A), which is controlled from outside the container via an attached metal rod that also ran through an outside access hole (Fig. 3C).

A rudimentary vacuum system was added to the PTU to facilitate heating packed boxes of plants (Fig. 4). A 4-cm-diameter hole was bored through each side of the shipping container to accommodate a 3.81-cm-diameter PVC pipe. On the outside of the unit, the PVC pipe was connected to the intake hose of a rigid, 12 gallon (45.4 liters), 5.0 peak HP wet/dry vacuum via a hose adapter (Home Depot, Atlanta, GA) (Fig. 4B). Inside the container, a series of PVC wands cut to fit the length of a standard strawberry box (Fig. 4C) were connected to the main vacuum line; each vacuum could draw enough air to support about five wands (i.e., treat five boxes; about 5,000 plants). Each PVC wand had $0.635-\mathrm{cm}$-diameter holes drilled every $5 \mathrm{~cm}$ through both sides along the length of the wand to facilitate the vacuum (Fig. 4C). Each box of plants contained a single wand, which was forcefully inserted into the bottom of a packed box of strawberry plants through an opening cut through the cardboard packaging (circled in Fig. 4A).

To monitor temperature within the PTU, a wooden scaffold was built to secure six temperature probes connected to a

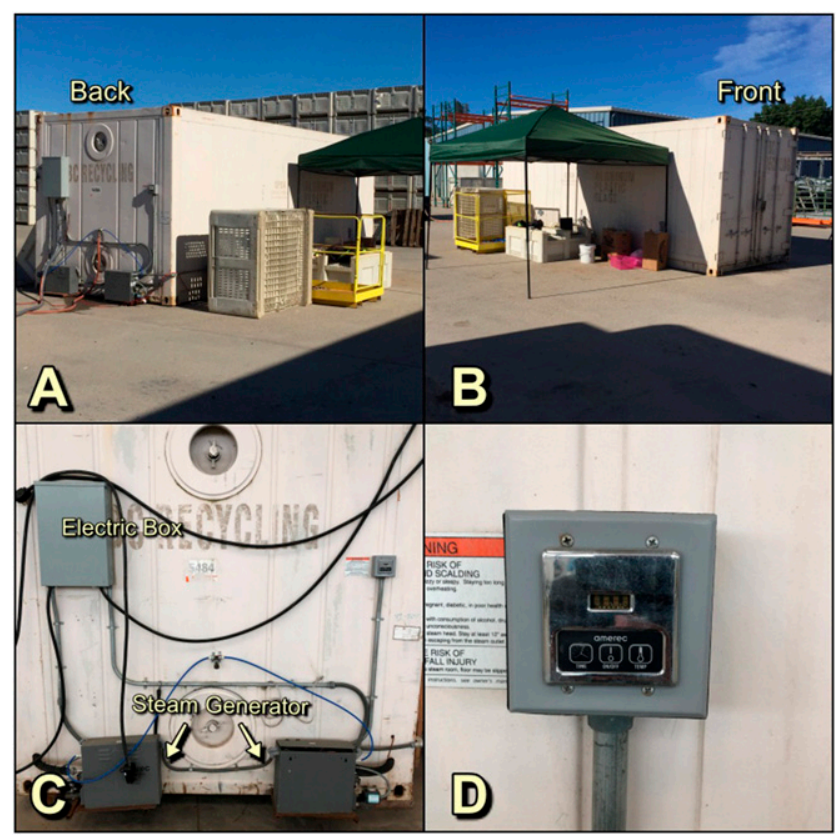

FIGURE 1

Exterior pictures of the rear $(\mathbf{A})$ and front $(\mathbf{B})$ sides of the precision thermotherapy unit, a retrofitted shipping container with outer dimension measurements of $\sim 6.05$ m length $\times 2.4$ m width $\times 2.4 \mathrm{~m}$ height. On the back side of the precision thermotherapy unit, an Amerec Steam Bath Generator (model 3K24) (C) consisting of a $3 \mathrm{~K} 12$ master generator and $3 \mathrm{G} 12$ slave generator is connected to an exterior water source with a standard garden hose and powered by a direct connection to a subpanel (electric box) mounted directly above the generators. The unit is controlled by a K60 Control Kit (D).
Campbell CR10X data logger (Campbell Scientific, Logan, UT) from $\sim 30 \mathrm{~cm}$ above the floor to $\sim 30 \mathrm{~cm}$ below the ceiling of the PTU chamber (Fig. 5A). Six additional probes were used for measuring temperature within boxes or bins of plants, one to three sensors per box/bin depending on the number of boxes being treated. The sensors were buried in the middle of the plants (Fig. 5B).

Research unit. A smaller research-scale unit was also constructed in April 2015 at the University of Florida's Gulf Coast Research and Education Center (UF-GCREC) in Wimauma, FL. The research-scale unit was constructed by retrofitting an old growth chamber $(\mathrm{OD} \sim 2.03 \mathrm{~m}$ length $\times 0.79 \mathrm{~m}$ width $\times 2.03 \mathrm{~m}$ height) with a single $3 \mathrm{~K} 8$ Amerec Steam Bath Generator controlled by a K60 Control Kit (Fig. 6A). The $8-\mathrm{kW}$ generator supplies up to $10.6 \mathrm{~kg}$ of steam per hour at maximum capacity with maximum vapor pressure of $0.5 \mathrm{kPa}$. A single copper line was introduced through an access hole near the floor at the back of the PTU and bent to run along the walls of the chamber. As with the walk-in generator, ten ventilation holes were drilled along the length of the copper piping at $30.5-\mathrm{cm}$ intervals beginning from the first hole, which was located about $20 \mathrm{~cm}$ from entry point, and were shielded by wooden baffles (Fig. 6B). No holes were drilled in the curved section of line, and the hole diameters were identical to those described above. Unlike the walk-in PTU, plants were typically unpacked from their boxes and laid in a shallow three- to five-plant layer on trays (Fig. 6C); thus, vacuum assistance was not added to the unit. Temperature within the chamber was monitored with digital thermometers (Fig. 6D).

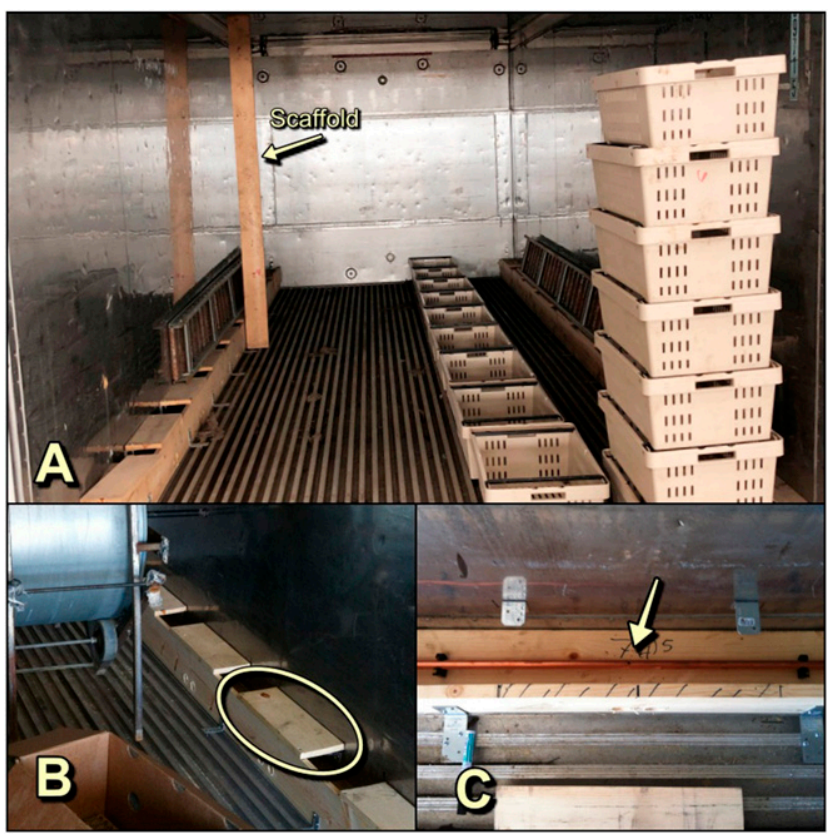

FIGURE 2

Interior pictures of the precision thermotherapy unit with interior dimensions of $\sim 5.7 \mathrm{~m}$ length $\times 2.3 \mathrm{~m}$ width $\times 2.1 \mathrm{~m}$ height $(\mathbf{A})$. Pictured are the scaffold that supports the temperature probes (none connected, but see Fig. 5A), standard bins used for holding plants (used in some of the trials), and roller tables stacked off to the side. The wooden duct and baffles (circled) $(B)$ are centered above the steam exit holes (C) drilled in the copper piping (arrow). In C, the wooden baffle was removed to expose the steam exit hole for the picture. 


\section{Disease management trials}

Two independent trials were conducted over two growing seasons (2016 and 2017) at the Picos Research Farm of the USDA-ARS U.S. Horticultural Research Laboratory in Fort Pierce, FL, to evaluate the efficacy of precision thermotherapy on reducing the incidence of ALS. In 2016, 'Portola' strawberry plants harvested from an infected field were used. In 2017, 'San Andreas' plants were sourced from the high-elevation trial conducted in Macdoel, CA, from plots with known ALS (see below). For each trial, four replications (= blocks) of three treatments included a nontreated control and a $44^{\circ} \mathrm{C} / 4 \mathrm{~h}$ heat treatment with and without the $37^{\circ} \mathrm{C} / 1 \mathrm{~h}$ conditioning treatment.

All heat treatments were applied using the research-scale PTU located at UF-GCREC in Wimauma, FL. In 2016, plants were treated on 29 February and then transported and planted in Fort Pierce on 1 March. In 2017, plants were treated on 14 December and then transported and planted in Fort Pierce on 15 December. Treated plants were planted into their designated plots located on one of four $0.76-\mathrm{m}$ raised beds covered with black plastic mulch. The beds were spaced $1.6 \mathrm{~m}$ apart. Plants were planted in a staggered double row, with plants spaced $25.4 \mathrm{~cm}$ apart within and between rows on a bed. Plots were approximately $3.65 \mathrm{~m}$ in length, similarly staggered between beds with $3.65 \mathrm{~m}$ spacing between plots. Plants were overhead irrigated for 2 to $3 \mathrm{~h}$ /day for 7 days for establishment and then daily using subsurface drip irrigation through a drip tape placed $\sim 2.5 \mathrm{~cm}$ below the top of the plastic mulched beds. In both years, plots consisted of 20 plants per treatment per replication. In 2016 but not 2017, straw mulch

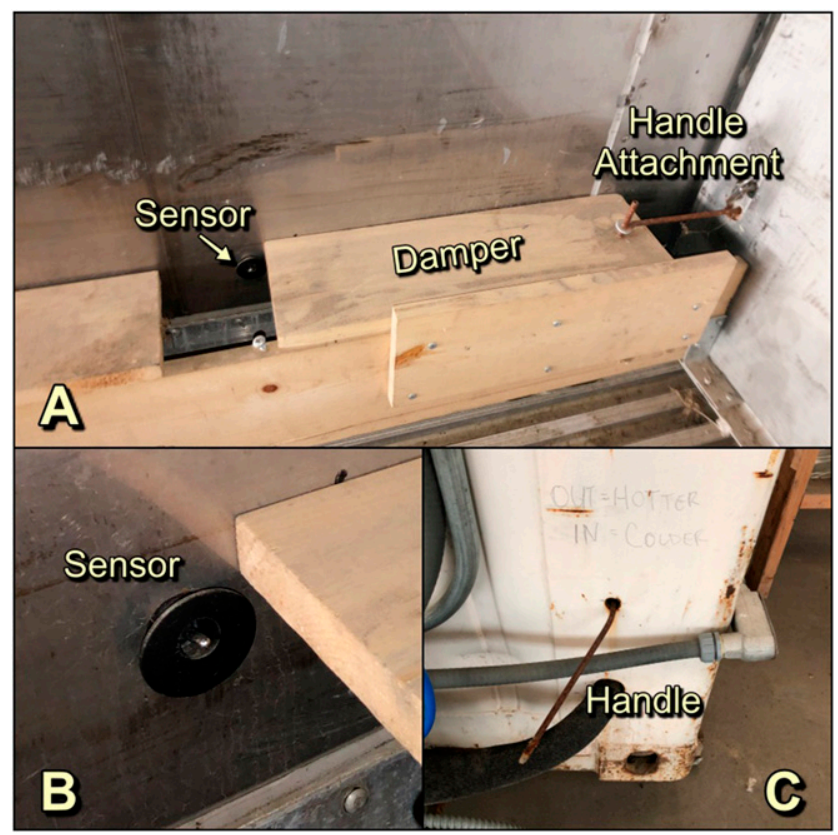

FIGURE 3

The wooden dampering mechanism used for fine regulation of temperature of the precision thermotherapy unit. A copper rod was attached to the wooden damper $(\mathbf{A})$, which rests on top of the copper pipe enclosure. From the outside (B and $\mathbf{C}$ ), the handle could be used to move the wooden damper closer to or farther away from the thermocouple to regulate the amount of steam contacting the thermocouple. Moving the wooden damper closer to the thermocouple forces the heated steam onto the thermocouple, raising the temperature at the thermocouple and causing the sauna unit to stop producing steam until the PTU cools below the programmed temperature. was laid in the row middle to reduce splash dispersal between plots (interplot interference); we were unable to procure clean straw in 2017. In 2016, plants were rated for ALS by counting the total number of healthy and infected leaves per plant on 21 and 28 March, 3, 11 and 21 April, and 5 May. In 2017, plants were similarly rated on 3, 16, and 26 January and 3 February.

Data analysis. Both experiments were designed as a randomized complete block with repeated measures (the plot). The proportion of infected plants per plot was transformed using the arcsine-square root transformation, where a plant was labeled infected if one or more leaves exhibited symptoms. A general linear mixed model was fit to the data using the MIXED procedure in SAS (version 9.4; SAS Institute, Cary, NC) with the default identity link function and Gaussian error structure, the maximum likelihood estimation method, and Kenward and Rogers degrees of freedom as options. The variables "treatment" and "date" were modeled as fixed effects and "block" as a random effect. Repeated measurements were modeled with a Toeplitz covariance structure after evaluation of other possible covariance structures. Akaike's information criteria and subjective evaluation of normality and residual plots were used for final model selection. Pairwise treatment differences for the fixed effect were obtained using the LSMEANS statement and PDIFF option $(P=0.05)$.

\section{Plant health and disease management trials}

Several independent trials were conducted over 4 years under commercial nursery production practices to evaluate: (i) the

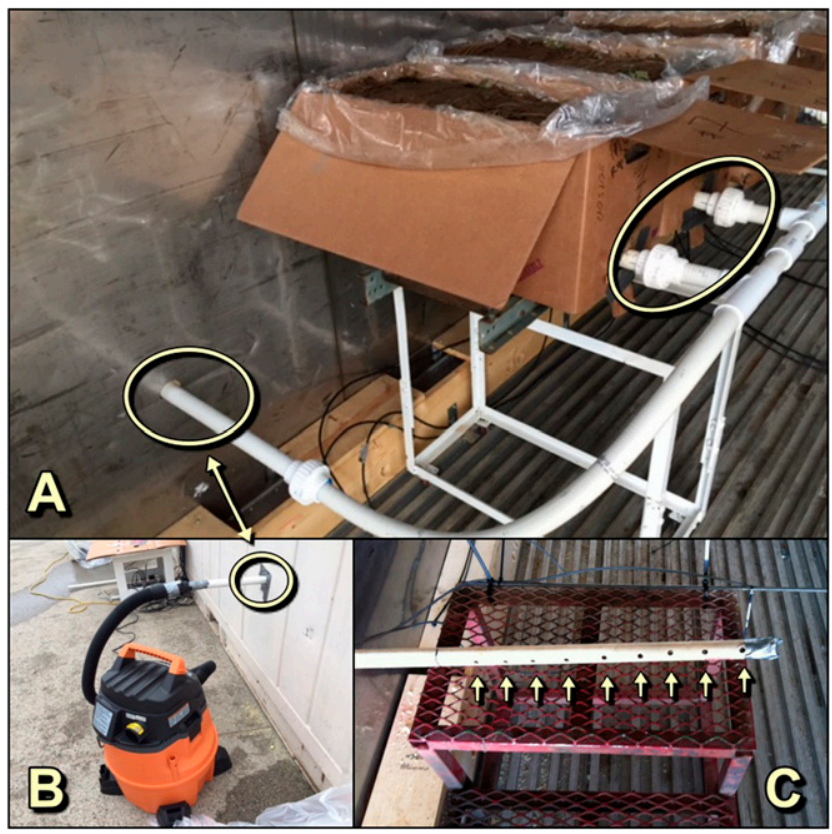

FIGURE 4

A, Vacuum system used to draw heated, saturated air evenly into the boxes. B, The PVC piping and wands are connected to a vacuum located on the outside of the precision thermotherapy unit. C, Each wand was cut to fit the length of a standard strawberry box and had $0.635-\mathrm{cm}$-diameter holes drilled every $5 \mathrm{~cm}$ through both sides along the length of the wand. The wands were connected to the main vacuum hose, and each wand was inserted into the bottom of a packed box of strawberry plants through an opening cut through the cardboard packaging. The strawberry box was then opened and the plastic liner peeled back to facilitate air movement. 
overall performance of the PTU and (ii) the $37^{\circ} \mathrm{C}$ conditioning for $1 \mathrm{~h}$ plus $44^{\circ} \mathrm{C}$ eradicative treatment for $4 \mathrm{~h}$ on plant growth, yield, and incidence of ALS. The performance of the PTU was quantified by monitoring the temperature inside the boxes or bins with transplants, and the impact of the thermal treatment was quantified by comparing plant health, yield, and ALS incidence to standard preplant practices. Trials were conducted in collaboration with four commercial nurseries at both low- and highelevation sites in California. Unlike the trials conducted in Fort Pierce, the pretreatment incidence of ALS in transplants across all experimental runs was presumed to be low because commercial nursery stock was used. Nurseries avoid harvesting and packing from diseased locations, but nevertheless it is nearly impossible to completely avoid disease. Reliable protocols for sampling and testing transplants prior to planting currently do not exist because of the difficulties, impracticalities, and uncertainties associated with testing at this stage of production (Turechek et al. 2008; Wang and Turechek 2020; Wang et al. 2018). Nonetheless, regular scouting after planting is a simple, reliable, and likely most sensitive method for detection at the field scale, and it is analogous to the "grow-out method" widely used in the seed industry.

Low-elevation nursery trials. Two trials, one each in 2015 and 2016, were conducted at low-elevation nursery sites in Manteca, CA, managed and operated by LCN. The PTU was transported from Redding (where it was built) to Manteca, CA, by tractor trailer and was connected to power and water the week prior to the beginning of each trial. In 2015, four treatments were applied to each of two cultivars ('Lucia' and 'Monterey') on June 9, 10, and 11 (one box per cultivar [= replication]/day): treatment 1 was the control (no thermal treatment), and treatments 2 to 4 were a $37^{\circ} \mathrm{C}$ conditioning treatment followed by an eradicative treatment of $44^{\circ} \mathrm{C}$ for 2,3 , or $4 \mathrm{~h}$, respectively. The trial was replicated June 20 and 21, 2016, with the exception that San Andreas replaced Lucia; both cultivars were subjected to all four treatments; two replications were run on June 20 and the third on June 21. For all

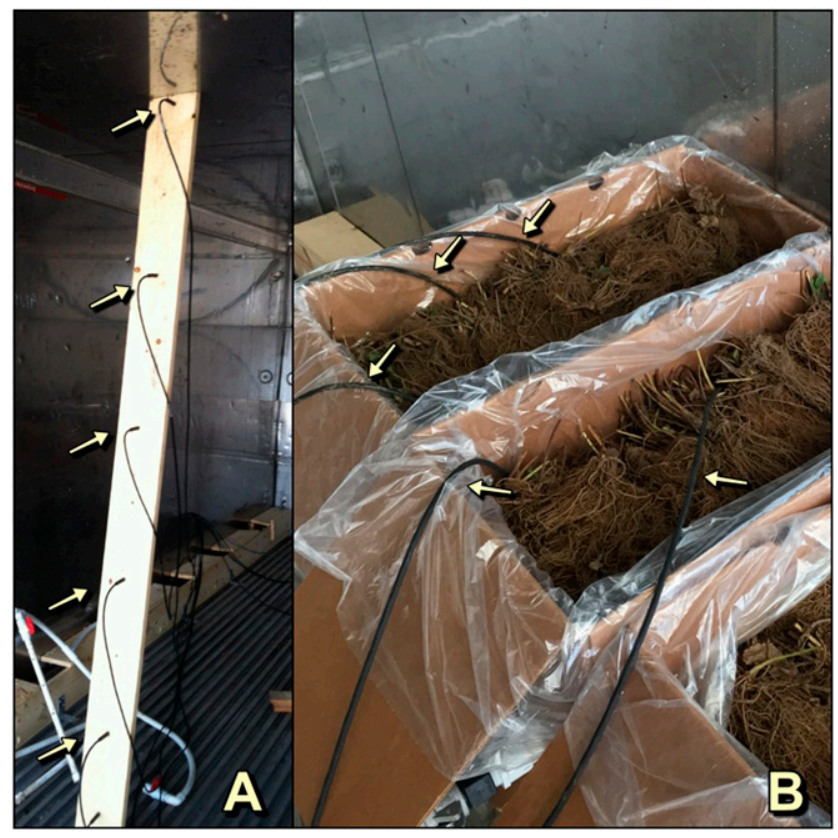

FIGURE 5

A, Wooden scaffold used to hold up to six thermocouples for monitoring the temperature within the precision thermotherapy unit. B, Thermocouples inserted into packed boxes of strawberry plants. trials, the $37^{\circ} \mathrm{C}$ conditioning treatment consisted of $1 \mathrm{~h}$ at $37^{\circ} \mathrm{C}$, followed by a $1 \mathrm{~h}$ cool-down period. For the cooling period, the steam generators were turned off, the shipping container doors and the back vent were opened, and ambient air was pulled through the boxes via vacuum to facilitate cooling to ambient temperature.

Treatments were applied to commercially packed boxes of 1,000 plants, but only 100 plants were sampled and planted from each treatment replicate in 2015 and 60 in 2016. Thus, for each replication, one box of each cultivar was placed in the PTU, conditioned, cooled, and then subjected to the $44^{\circ} \mathrm{C}$ eradicative treatment. The PTU was opened at 2,3 , and $4 \mathrm{~h}$ to retrieve 100 (60) plants for the respective treatment, as can be seen in the dips in the temperature profiles (Fig. 7). In practice, more than 100 (60) plants were pulled from the box at the 2, 3, and $4 \mathrm{~h}$ time periods. In an effort to collect a representative sample of plants from the box, approximately 200 to 300 plants were quickly collected from throughout the box at each time, and then 100 (60) were arbitrarily chosen from that batch. Not only did this help to ensure a representative sample, but it also facilitated a rapid entry and exit from the PTU. After the final treatment on each day, the plants were bagged by treatment in Ziplock bags and stored overnight in a cooler set at $-4^{\circ} \mathrm{C}$ for planting the next day.

For each cultivar, the plots were arranged in a randomized complete block design with three blocks (i.e., cultivars were planted in separate rows, and treatments were blocked and randomized with rows). In 2015, plots consisted of 100 plants in

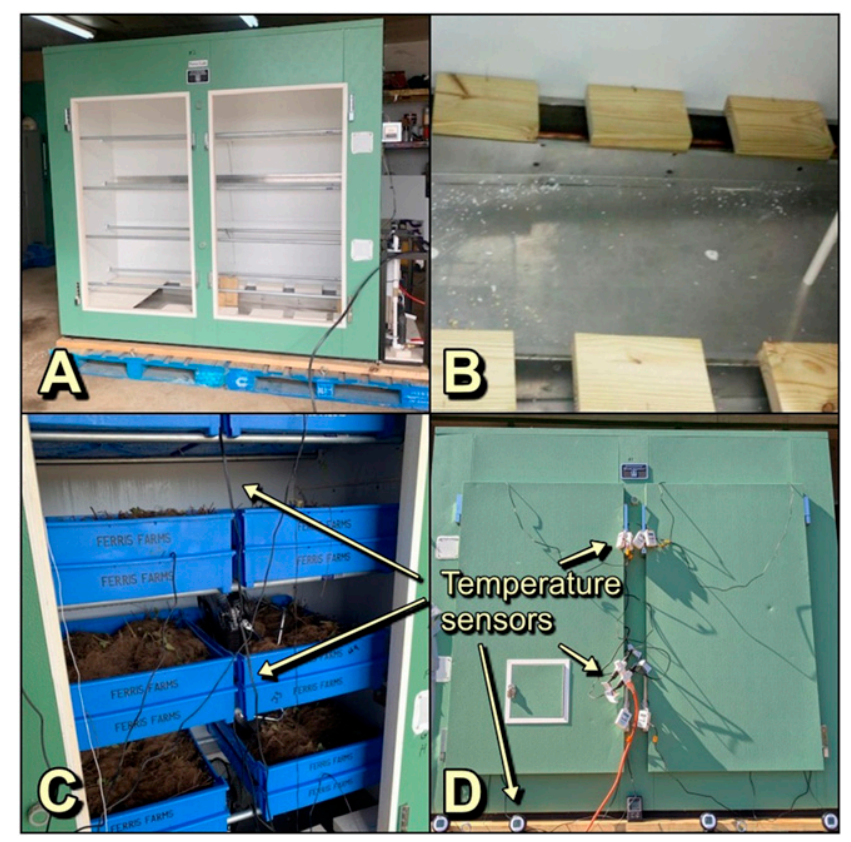

FIGURE 6

Exterior picture $(\mathbf{A})$ of the research- or small-scale precision thermotherapy unit, a repurposed growth chamber with outer dimensions of $\sim 2.03 \mathrm{~m}$ length $\times 0.79 \mathrm{~m}$ width $\times 2.03 \mathrm{~m}$ height. On the side of the precision thermotherapy unit is an Amerec Steam Bath Generator (model 3K8) connected to an exterior water source with a standard garden hose and powered by a direct connection to a subpanel (electric box) mounted directly above the generators. The wooden baffles (B) are centered above, and standard bins are used for holding plants (C). Data loggers and temperature sensors (D) inserted into packed boxes of strawberry plants and various locations in the chamber are read from the outside of the chamber and the data recorded. 
two rows spaced $1.5 \mathrm{~m}$ apart with 50 plants per row set every $0.61 \mathrm{~m}$. Plots were spaced $3.0 \mathrm{~m}$ apart across rows (i.e., a skiprow between neighboring plots) and $7.6 \mathrm{~m}$ between plots within row. In 2016, plots consisted of 60 plants in two rows spaced $1.82 \mathrm{~m}$ apart with 30 plants per row set every $0.61 \mathrm{~m}$. Plots were spaced $1.82 \mathrm{~m}$ apart across rows (i.e., a skip-row between neighboring plots) and $\sim 7.6 \mathrm{~m}$ between plots within row. In both years, plants were planted and maintained in accordance with standard commercial practices and regularly inspected throughout the duration of the planting by personnel at LCN.
On October 21 and 22, 2015, plants were rated midseason for their growth and surveyed for the incidence of ALS. Each plot was rated at 16 evenly spaced locations, eight on each side of the bed. The term bed is used because the plants in the two rows filled the $1.5-\mathrm{m}$ space between them with daughter plants to create a continuous mat of plants. At each stop, growth was assessed visually on a 1-to- 4 scale as follows: $1=$ full stand; $2=\leq 25 \%$ reduction in stand; $3=>25 \%$ and $<75 \%$ reduction in stand; and $4=\geq 75 \%$ reduction in stand. A final survey for ALS was done on January 16, 2016, using the same sampling technique as above,

\section{FIGURE 7}

Temperature profile of the large precision thermotherapy unit and packaged strawberry boxes for the three experimental replicates of the 2015 low-elevation nursery trial. Thermocouples were buried halfway deep in each box of plants at three locations (front, middle, and back), with the set for 'Monterey' shown as solid lines and for 'Lucia' as dashed-dotted lines. The data from the set of six thermocouples mounted to the wooden scaffold (Fig. 5A) to monitor the interior temperature of the precision thermotherapy unit are shown as dotted lines.
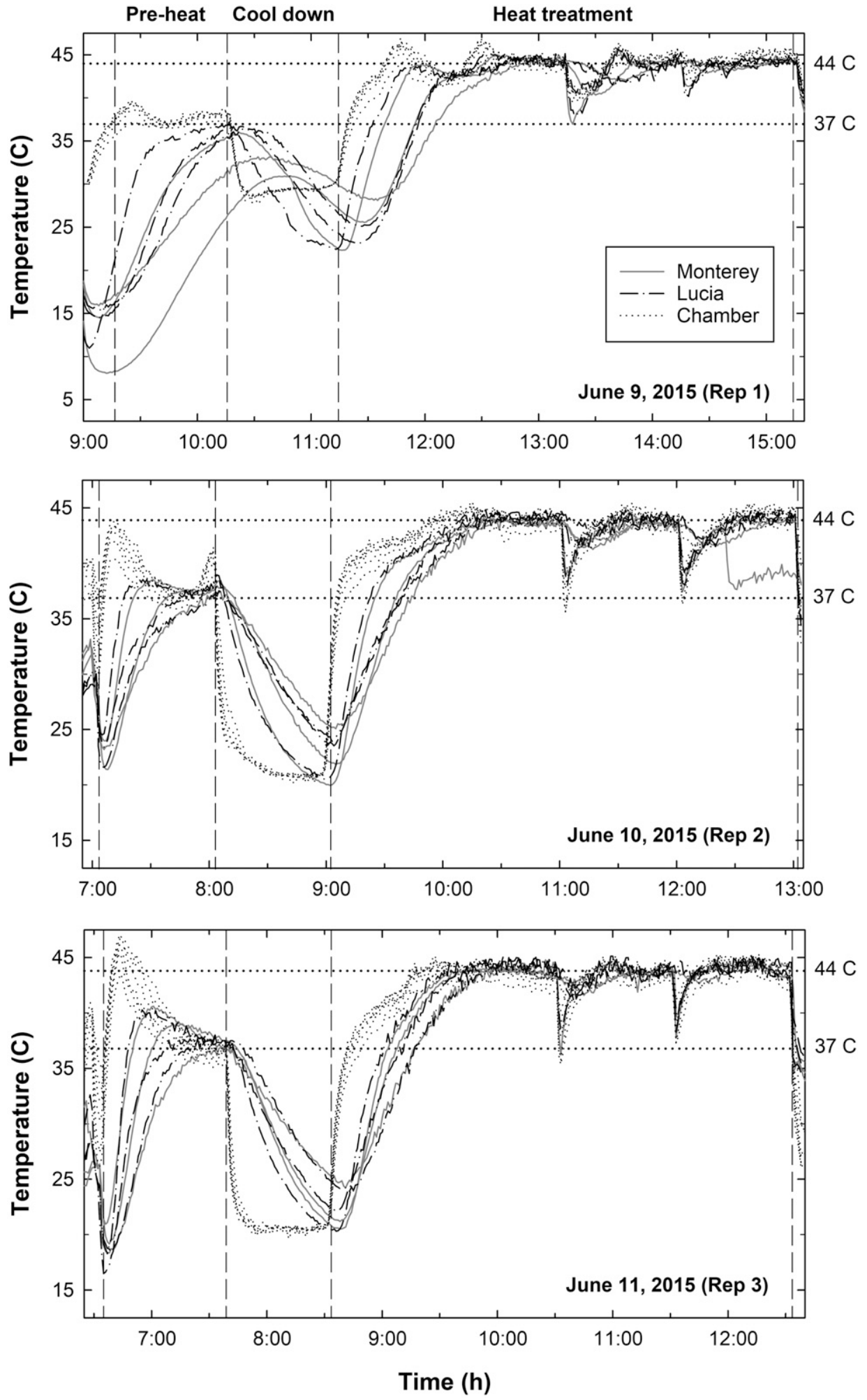
but no ALS was found. The plots were harvested, trimmed, and packed on January 27, 2016. For the 2016 planting, plants were surveyed and rated for growth and ALS on September 7, 2016 (midseason) and January 9, 2017. Each plot was rated at 10 evenly spaced locations across the bed. Plants were harvested on February 1, 2017, and trimmed and packed the following day. All harvesting activities were done by the crew at LCN.

High-elevation nursery trial. This trial was conducted at a high-elevation nursery site in Macdoel, CA, managed and operated by LCN. The PTU was transported back to Redding from Manteca and was set up the week before the trial. Prior to running the trial, a more elaborate vacuum system was built to accommodate 18 boxes of plants, 15 more than the previous setup (Fig. $8 \mathrm{~A}$ ). The expanded system introduced three additional shop vacuums, about $30 \mathrm{~m}$ of PVC, $8 \mathrm{~m}$ of flexible PVC, and various coupling devices. The system was assembled over the course of 2 days. Further details are omitted because it was abandoned after its first use due to technical issues (see Results). With the ability to treat 18 boxes at once, the three-replication trial was conducted in a single day.

This trial was designed primarily to test the use of thermotherapy on plants destined for high-elevation plantings - the environmental conditions at high elevation are markedly different than low-elevation nurseries. The trial was conducted on April 26, 2016, with cultivars Monterey and San Andreas. Three treatments included: (i) control (no thermal treatment); (ii) $37^{\circ} \mathrm{C}$ conditioning treatment followed by $44^{\circ} \mathrm{C}$ for $4 \mathrm{~h}$ eradicative treatment; and (iii) $44^{\circ} \mathrm{C}$ for $4 \mathrm{~h}$ (no conditioning treatment). As with the low-elevation trials, the $37^{\circ} \mathrm{C}$ conditioning treatment consisted of $1 \mathrm{~h}$ of heating at $37^{\circ} \mathrm{C}$, followed by a 1-h cool-down period. Boxes of 1,000 plants were treated, but only 200 plants were needed for each treatment replicate. After the plants were treated, they were stored overnight in a cooler set at $-4^{\circ} \mathrm{C}$ for planting the following morning.

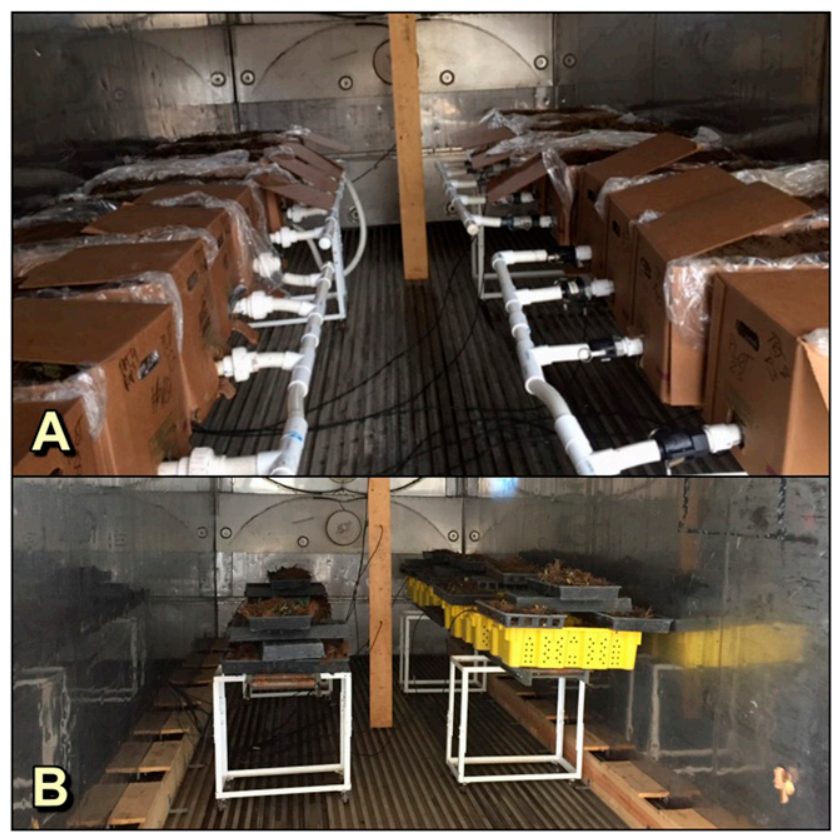

FIGURE 8

A, The precision thermotherapy unit setup for the high-elevation nursery trial in 2016. The extended setup allowed treatment of 18 boxes and employed four vacuums. B, The setup used for the trials run at Escalon and Ballico in 2017. A similar setup was used for the grower-run trial in 2018.
For each cultivar, the plots were arranged in a randomized complete block design with three blocks (i.e., cultivars were planted in separate rows, and treatments were blocked and randomized within rows). Plots consisted of 200 plants in two rows spaced $1.5 \mathrm{~m}$ apart with 100 plants per row set every $0.305 \mathrm{~m}$. Plots were spaced $3.0 \mathrm{~m}$ apart between and across rows (i.e., a skip-row between neighboring plots). Plants were maintained in accordance with standard commercial practices.

Plants were rated for growth and ALS twice during the growing season: May 25 and September 6, 2016. On May 25, plants were assessed visually for growth using the 4-point rating scale defined above. Each plot was rated at 10 evenly spaced locations across the bed. On September 6, plants were rated for incidence of ALS. At each stop, 10 leaves were arbitrarily selected and rated for the presence of symptoms. Plants were harvested on November 11, 2016, and then trimmed and packed the following day by the crew at LCN.

Thermotherapy versus industry standards. Two trials were conducted at two low-elevation nursery sites to compare the thermotherapy protocol treatment against the standard practices of hot water and/or fungicide dip treatments; these essentially served as the control treatments in the trials described below. One planting managed by Plant Sciences, Inc., was located near Escalon, CA. The other planting located near Ballico, CA, was managed by Driscoll's/Sierra-Cascade Nursery. At the Escalon location, three treatments were evaluated using a numbered selection (PE 7.2059): (i) hot-water dip (control), (ii) fungicide dip, and (iii) $37^{\circ} \mathrm{C}$ conditioning treatment followed by $44^{\circ} \mathrm{C}$ for 4 h. At Ballico, two treatments were evaluated using the cultivar 'Amado': (i) hot-water dip (control) and (ii) $37^{\circ} \mathrm{C}$ conditioning treatment followed by $44^{\circ} \mathrm{C}$ for $4 \mathrm{~h}$. For hot-water dipping, plants were exposed to three consecutive dips of $7 \mathrm{~min}$ each $-37.8^{\circ} \mathrm{C}$ (conditioning), $49^{\circ} \mathrm{C}$ (treatment), and ambient temperature (cooling) - and were treated by personnel at the cooperating nursery. Preplant fungicide dips were done by nursery personnel using Switch 62.5WG (cyprodinil + fludioxonil) (Syngenta Crop Protection, Greensboro, NC) according to the manufacturer's label instructions. Hot-water-dip and fungicide-dip treatments were completed the day before planting. For the thermotherapy treatment, the requisite number of plants were removed from commercially packed boxes and placed in layers two to four plants deep on $25.4 \times 50.8 \mathrm{~cm}$ mesh plastic trays. The trays were stacked in a manner to facilitate penetration of the aerated steam. Vacuum assistance was not used in this trial (Fig. 8B). Plants for both locations were treated in the PTU on May 25, 2017. All treatments were planted on May 30, 2017, by nursery personnel (no more than 5 days after PTU treatment).

At Escalon, plots were arranged in a straight line of nine plots, blocked in three groups of three treatments (PTU, hot-water dip, fungicide dip). Each plot consisted of four 15.24-m-long rows with plants set every $0.61 \mathrm{~m}$ within rows. There was $1.22 \mathrm{~m}$ between rows and $2.44 \mathrm{~m}$ between consecutive plots. At Ballico, plots were arranged in a straight line of eight plots, blocked in four groups of two treatments (PTU, hot-water dipped). Each plot consisted of nine 9.14-m rows with $\sim 1.22 \mathrm{~m}$ between rows (drive rows were a little larger) and $3.66 \mathrm{~m}$ between consecutive plots, with plants set at $0.254 \mathrm{~m}$ within rows.

Plants were rated for growth and incidence of ALS twice during the growing season: July 28 and 29, 2017 (midseason) and November 28 and 29, 2017. At Ballico, each plot was rated at 48 evenly spaced locations across the plot (eight sets of six), and at $\sim 33$ locations (three sets of 11) at Escalon. Plants were harvested December 28, 2017, at Ballico and on January 30, 2018, at Escalon. The plants were trimmed and packed the following day by the respective farm crews. The entire plot was harvested at 
Escalon. At Ballico, a subset of plants was harvested by hand digging all the plants within a $1 \times 1-\mathrm{m}$ wooden frame placed at six evenly spaced locations diagonally across the plot and then summing the six values for a plot-level estimate of yield.

Grower-run trial. A validation trial was conducted at a lowelevation nursery site located near Ballico, CA, managed by Driscoll's/Sierra-Cascade Nursery. This trial was a designed to be a repeat of the trial above, with the exception that the entire process was conducted by nursery personnel. The plants were treated on July 19, planted on July 21, and harvested and packed on December 6, 2018, following the procedures outlined in the previous trial. ALS data were assessed by nursery personnel by estimating the length of row in each plot affected and then calculating the number of mother plants in the affected portion.

Data analysis. For each trial, the dependent variable "midseason rating" was analyzed by cultivar using the nonparametric Friedman test for randomized block design, with "treatment" and "replication" (= block) serving as the independent variables. The dependent variable "plant yield" was analyzed by cultivar without transformation in a general linear mixed model specifying an identity link function and Gaussian (normal) error distribution. The independent variable "treatment" was considered a fixed effect, and "replication" (= block) a random effect. The dependent variable "ALS" (a proportion) was arcsine-square root transformed and analyzed in a general linear mixed model specifying an identity link function and Gaussian (normal) error distribution. The independent variable "treatment" was considered a fixed effect and "replication" (= block) a random effect. Friedman's test was performed using Minitab (version 19; Minitab, State College, PA). The mixed model analyses were performed with the PROC GLIMMIX procedure of SAS (version 9.4). Standardized residual and normality plots were used to determine the adequacy of model fit. Pairwise treatment differences for the fixed effect were obtained using the LSMEANS statement and LINES option $(P=0.05)$. Significance of the random effect was tested using the COVTEST statement and WALD option $(P=0.05)$.

\section{RESULTS}

\section{PTU design and construction}

Both units were able to maintain a consistent and even temperature throughout the chamber once equilibrium was achieved (see below). As expected, the chamber heats at a quicker rate than the plants within the chamber; thus, monitoring the temperatures of both the chamber and plants until equilibrium is established is necessary to ensure accuracy of the treatment. Because of the differential rates in heating, it is best to set the temperature of the chamber a few degrees higher than the target temperature until plants near the target temperature. Vacuum assistance hastens this process when packed boxes are used, but when too much vacuum was applied the distribution of heat within the chamber became uneven, making it difficult to achieve equilibrium. How exactly vacuum assistance interacts with temperature stability is complicated, and elucidating this was beyond the scope of this research. The use of a rack system, for which vacuum assistance is not needed, eliminates the vacuum factor (e.g., Fig. 6C). In all cases, the rate of plant heating and the time needed to reach target temperature are dependent on the initial temperature of plants. As noted below, it is advised that plants be removed from cold storage $24 \mathrm{~h}$ prior to application of thermotherapy and the conditioning treatment. After conditioning, the rate of temperature increase during the eradicative treatment was shown to be fairly uniform across trials.
The costs for the generator(s), drain assembly, and control kit was approximately $\$ 5,000$ for the large commercial unit and $\$ 2,600$ for the research unit. In both cases, the "container" was an existing container that was repurposed for the project and thus was not factored into the cost. However, if no container is available for repurposing, one can be purchased or constructed, and the cost would be dependent on the size and materials used. We have no specific recommendations except that the container should be insulated to retain heat. The copper piping and materials for duct work (wooden boards and fasteners) are priced by the length, but for a medium-sized unit the material costs should not exceed \$500. Digital panel thermometers with sensors and a 3-m cable for monitoring the chamber temperature can be purchased for approximately $\$ 20$ to $\$ 30$ each. If recording temperature is desired, as was done here, the cost for data loggers can significantly increase the cost. A Campbell Scientific CR1000X (replaces the CR10 and CR1000) with enclosure and cables will cost nearly $\$ 3,000$; the discontinued CR10 was used in the larger PTU. WatchDog 1000 Series Micro Stations were used in the smaller chamber and cost $\sim \$ 275 /$ each (Spectrum Technologies, Aurora, IL).

\section{Disease management trials}

ALS developed in both the 2016 and 2017 trials, but disease incidence and severity were greater in the 2016 trials (Fig. 9). ALS incidence was significantly lower in the PTU-treated plots in both trials. In 2016, plants receiving the preconditioning treatment had significantly lower ALS incidence than plants that did not receive the preconditioning treatment (Table 1).

\section{Low-elevation nursery trials}

PTU performance. The temperature profile within the PTU chamber (six sensors) and within each of the two boxes of plants (three sensors per box) is shown in Figure 7 for the low-elevation trial performed in 2015. In replication 1, it generally took $1 \mathrm{~h}$ or more for most of the boxes to reach $37^{\circ} \mathrm{C}$ during the conditioning treatment. Thus, in replications 2 and 3, the thermostat was set above the target temperature of $37^{\circ} \mathrm{C}$ to quickly raise the temperature of the plants to $37^{\circ} \mathrm{C}$ during the conditioning treatment and then set back to $37^{\circ} \mathrm{C}$ when the target temperature was achieved. Exposure to temperatures $>37^{\circ} \mathrm{C}$ during these runs occurred during the conditioning treatment but did not exceed 30 min. It should be noted that the boxed plants used on day 1 were not fully thawed at the beginning of experiment; ice was present on plants at the start of the conditioning treatment. On days 2 and 3 , the plants were sufficiently thawed. This difference is seen by noting that the minimum value on the $y$ axis on day 1 is $\sim 5^{\circ} \mathrm{C}$, whereas on the other two days it is $\sim 15^{\circ} \mathrm{C}$ (Fig. 7). For the 1-h cool-down period, the minimum temperature is constrained by the ambient air temperature; thus, it differed slightly between the two low-elevation trials. In applying the $44^{\circ} \mathrm{C}$ eradicative treatment, it took approximately $90 \mathrm{~min}$ for all sensors within the box to reach the target temperature. In all three replications, the rise in temperature within the boxed plants lagged that of the chamber, but once the target temperature was achieved, it was universally stable. Fluctuations in temperature were only noticed when the chamber was opened to retrieve the plants. Similar temperature profiles were observed during the low-elevation trial in 2016 (data not shown)

Plant health and yield. Assessment of plant health at midseason showed no significant differences in growth and establishment among replications for either Monterey $(P=0.194)$ or 
Lucia $(P=0.719)$ in 2015 or Monterey $(P=0.488)$ or San Andreas $(P=0.484)$ in 2016 (Table 2; Fig. 10A and B). The average rating across all treatments was approximately 1.13 and 1.24 for Monterey and Lucia, respectively, in 2015. A fully established stand would receive a value of 1 . In 2016, the average ratings were higher at 1.67 and 2.54 for Monterey and San Andreas, respectively. In 2016, the plots did not fill out as well as

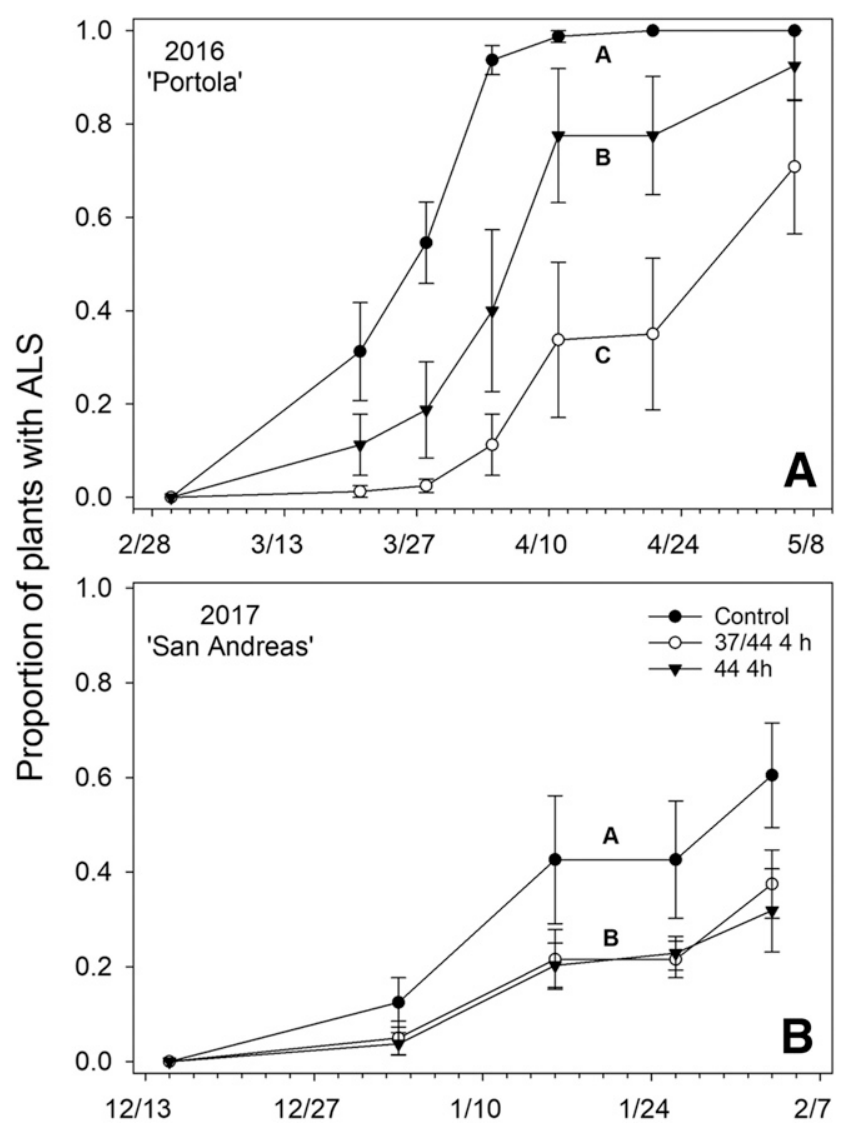

FIGURE 9

Disease progress of angular leaf spot (ALS) of strawberry in smallplot trials conducted at the Picos Research Farm of the USDAARS U.S. Horticultural Research Laboratory in Fort Pierce, FL. Trials consisted of four replications of a nontreated control and precision thermal treatments of $44^{\circ} \mathrm{C} / 4 \mathrm{~h}$ eradication heat treatment with and without the $37^{\circ} \mathrm{C} / 1 \mathrm{~h}$ conditioning treatment. A, The trial in 2016 used a known source of infected 'Portola' plants. B, In 2017, plants were sourced from the high-elevation trial conducted in Macdoel, CA, from plots with known ALS (Fig. 13A). Symbols and whiskers represent the proportion of plants with ALS and their standard errors. Lines sharing the same letter are statistically equivalent according to a mixed-model analysis. they did in 2015, but the surviving plants were in good health. In both years, no ALS was detected in the treated or control plots.

There were differences in yields among treatments within cultivar (Fig. 11A and B). Absolute yields were lower in 2016 than in 2015 due to the smaller number of plants planted initially per plot. Significant differences in yield were found among the thermal treatments with Monterey in 2015 (Table 3; Fig. 11A). The $37^{\circ} \mathrm{C}$ conditioning followed by the $44^{\circ} \mathrm{C}$ for $4 \mathrm{~h}$ eradicative treatment yielded fewer daughter plants than plants exposed to the eradicative treatment for 2 or $3 \mathrm{~h}$. However, that same $44^{\circ} \mathrm{C} /$ $4 \mathrm{~h}$ treatment was not significantly different from the control. There were no significant differences in yields among treatments for Lucia, but the variability among treated plots was higher in Lucia than Monterey plots. At the final rating, no ALS was found in any of the plots in either 2015 or 2016.

\section{High-elevation nursery trial}

PTU performance. The temperature profile within the PTU chamber (two sensors) and within each of 10 boxes of plants is shown in Figure 12. Because 18 boxes (all three replications) were treated at the same time, not all boxes were equipped with a temperature sensor due to the limited number (12) of sensors (Fig. 8A). There was a clear effect on both the precision and accuracy of the temperature achieved within the chamber and boxes due to the operation of four vacuums, as opposed to the one used in the 2015 (first) low-elevation trial. The addition of three

\section{TABLE 2}

Friedman test results examining the effect of precision thermotherapy (= aerated steam) treatment on strawberry plant health during midseason in five trials conducted over 4 years on several cultivars at both highand low-elevation nursery sites in California

\begin{tabular}{lcccccc}
\hline & & & & \multicolumn{3}{c}{ Friedman test $^{\mathrm{b}}$} \\
\cline { 5 - 7 } Trial $^{\mathrm{a}}$ & Year & Location & Cultivar & $d f$ & $\chi^{2}$ & $P$ value \\
\hline 1 & 2015 & Manteca & Monterey & 3 & 4.71 & 0.194 \\
1 & 2015 & Manteca & Lucia & 3 & 1.34 & 0.719 \\
2 & 2016 & Macdoel & Monterey & 2 & 6.00 & 0.050 \\
2 & 2016 & Macdoel & San Andreas & 2 & 4.67 & 0.097 \\
3 & 2016 & Manteca & Monterey & 3 & 2.43 & 0.488 \\
3 & 2016 & Manteca & San Andreas & 3 & 2.45 & 0.484 \\
4 & 2017 & Escalon & PE 7.2059 & 2 & 0.67 & 0.717 \\
4 & 2017 & Ballico & Amado & 1 & 1.00 & 0.317 \\
5 & 2018 & Ballico & Amado & 1 & 0.00 & 1.000 \\
\hline
\end{tabular}

${ }^{a}$ In trials 1,2 , and 3 , two cultivars were tested at each location. In trial 4, two cultivars at two locations were tested.

b The test statistic for the Friedman test has an approximately $\chi^{2}$ distribution, with associated degrees of freedom $(d f)$ of $(k-1)$, where $k$ is the number of treatments. If the data within one or more blocks have ties, the average ranks are used, and the test statistic is adjusted for ties.

TABLE 1

Type III tests from linear mixed-model analyses examining the effect of aerated steam treatment (fixed effect) on angular leaf spot of strawberry in two field trials conducted over 2 years at the Picos Research Farm of the USDA-ARS U.S. Horticultural Research Laboratory in Fort Pierce, FL

\begin{tabular}{|c|c|c|c|c|c|c|c|c|c|}
\hline \multirow[b]{3}{*}{ Year } & \multicolumn{9}{|c|}{ Type III tests of fixed effects ${ }^{\mathrm{a}}$} \\
\hline & \multicolumn{3}{|c|}{ Treatment } & \multicolumn{3}{|c|}{ Date } & \multicolumn{3}{|c|}{ Treatment $\times$ date } \\
\hline & Num/Den $d f$ & $F$ value & $\operatorname{Pr}>F$ & Num/Den $d f$ & $F$ value & $\operatorname{Pr}>F$ & Num/Den $d f$ & $F$ value & $\operatorname{Pr}>F$ \\
\hline 2016 & $2 / 18.7$ & 19.74 & $<0.0001$ & $6 / 23.3$ & 39.96 & $<0.0001$ & $12 / 23.3$ & 6.23 & $<0.0001$ \\
\hline 2017 & $2 / 17.5$ & 4.34 & 0.0296 & $4 / 19.8$ & 36.61 & $<0.0001$ & $8 / 19.8$ & 0.89 & 0.5414 \\
\hline
\end{tabular}

${ }^{a}$ Numerator (Num) and denominator (Den) degrees of freedom $(d f)$, the $F$ statistic $(F)$, and its associated probability $(\operatorname{Pr}>F)$ for each trial and cultivar combination. 
vacuums recirculated and/or removed the heated saturated air faster than the steam generators were able to replace it to maintain a stable temperature, as observed in the 2015 low-elevation trial. The temperature profile was more variable in the PTU and failed to stabilize at the target temperature of $44^{\circ} \mathrm{C}$. Indeed, many sensors recorded temperatures consistently above $44^{\circ} \mathrm{C}$, approaching $48^{\circ} \mathrm{C}$.
Plant health, yield, and ALS. At the midseason assessment, an adverse effect on plant growth was observed on Monterey $(P=$ 0.050) and San Andreas $(P=0.097)$ plants subjected to thermotherapy (Table 2; Fig. 10C). Although not compared directly, there appeared to be a cultivar effect with Monterey being more tolerant to thermotherapy than San Andreas (average ratings of
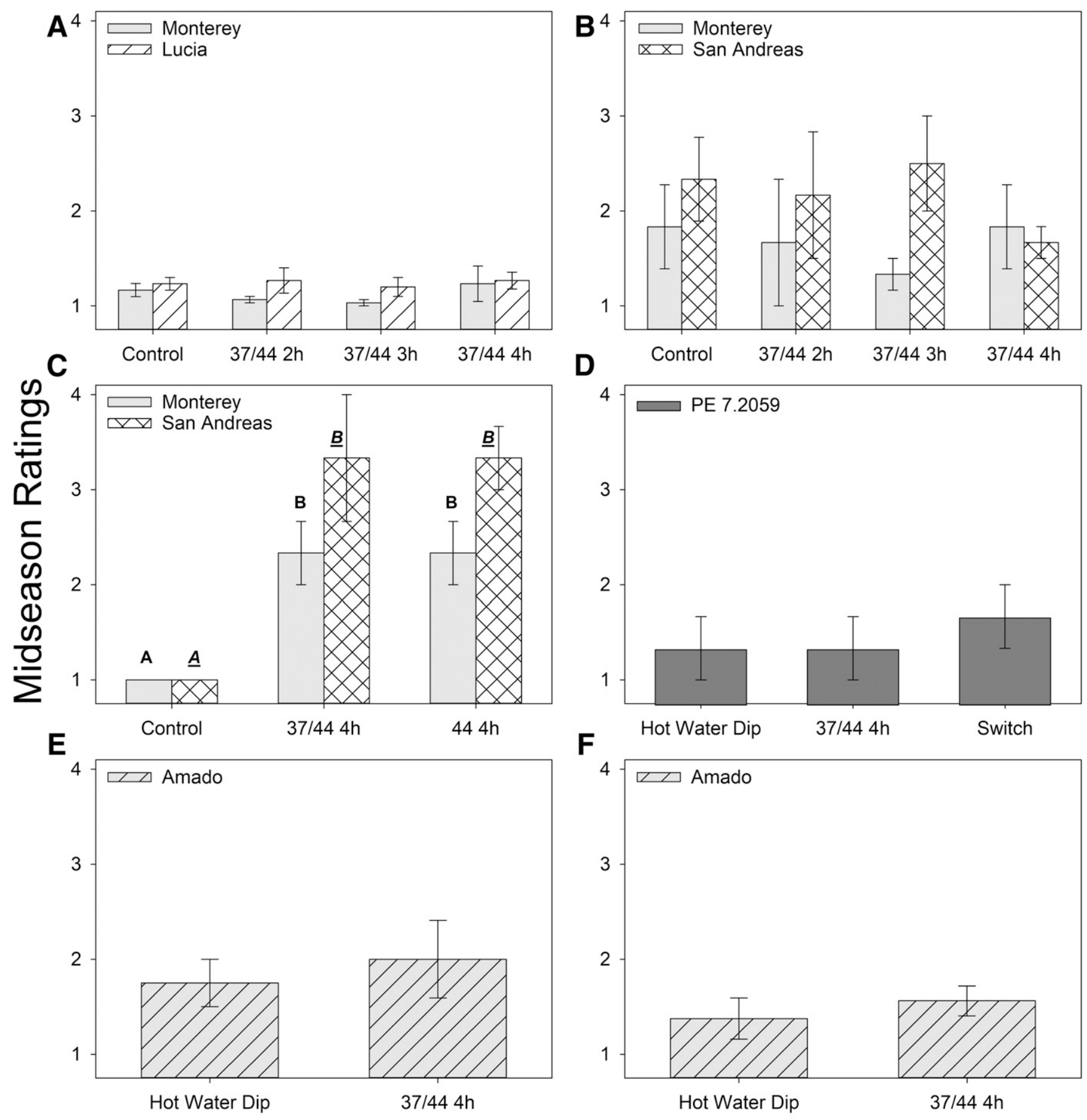

Treatment

FIGURE 10

Midseason plant health ratings for the low-elevation nursery trials conducted in Manteca, CA, in 2015 (A) and 2016 (B); the high-elevation trial conducted in Macdoel, CA, in 2016 (C); the low-elevation trials conducted in 2017 at Escalon (D) and Ballico, CA (E), and in 2018 at Ballico, CA (F). Plots were rated using between 10 and 33 evenly spaced locations depending on the size and geometry of the plots. At each stop, plants were assessed visually for health on a 1-to- 4 scale as follows: $1=$ full stand; $2=\leq 25 \%$ reduction in stand; $3=>25 \%$ and $<75 \%$ reduction in stand; and $4=\geq 75 \%$ reduction in stand. Bars represent the average rating, and their standard errors are shown for each treatment and cultivar where applicable. Data were analyzed using the rank-based Friedman test. Where significant differences occurred, bars that do not share the same letter within a cultivar set are significantly different. 
2.33 versus 3.33 , respectively). Nevertheless, this effect on growth was transient, and plants appeared to fully recover by harvest based on yield. In general, plant yields for San Andreas were lower than Monterey. For both cultivars, there were no significant differences among the treatments (Table 3; Fig. 11C). Nonetheless, both thermotherapeutic treatments yielded $\sim 2,700$ $(\sim 35 \%)$ more plants on average than the control for Monterey despite the lack of statistical significance. For San Andreas, the thermotherapeutic treatments yielded $\sim 1,300(\sim 18.5 \%)$ fewer plants than the control. At harvest, ALS was found in San Andreas but not Monterey (Fig. 13A). Although not significantly different, the highest incidence of ALS was found in the control plots and the lowest in the thermotherapy with conditioning treatment (Table 4).
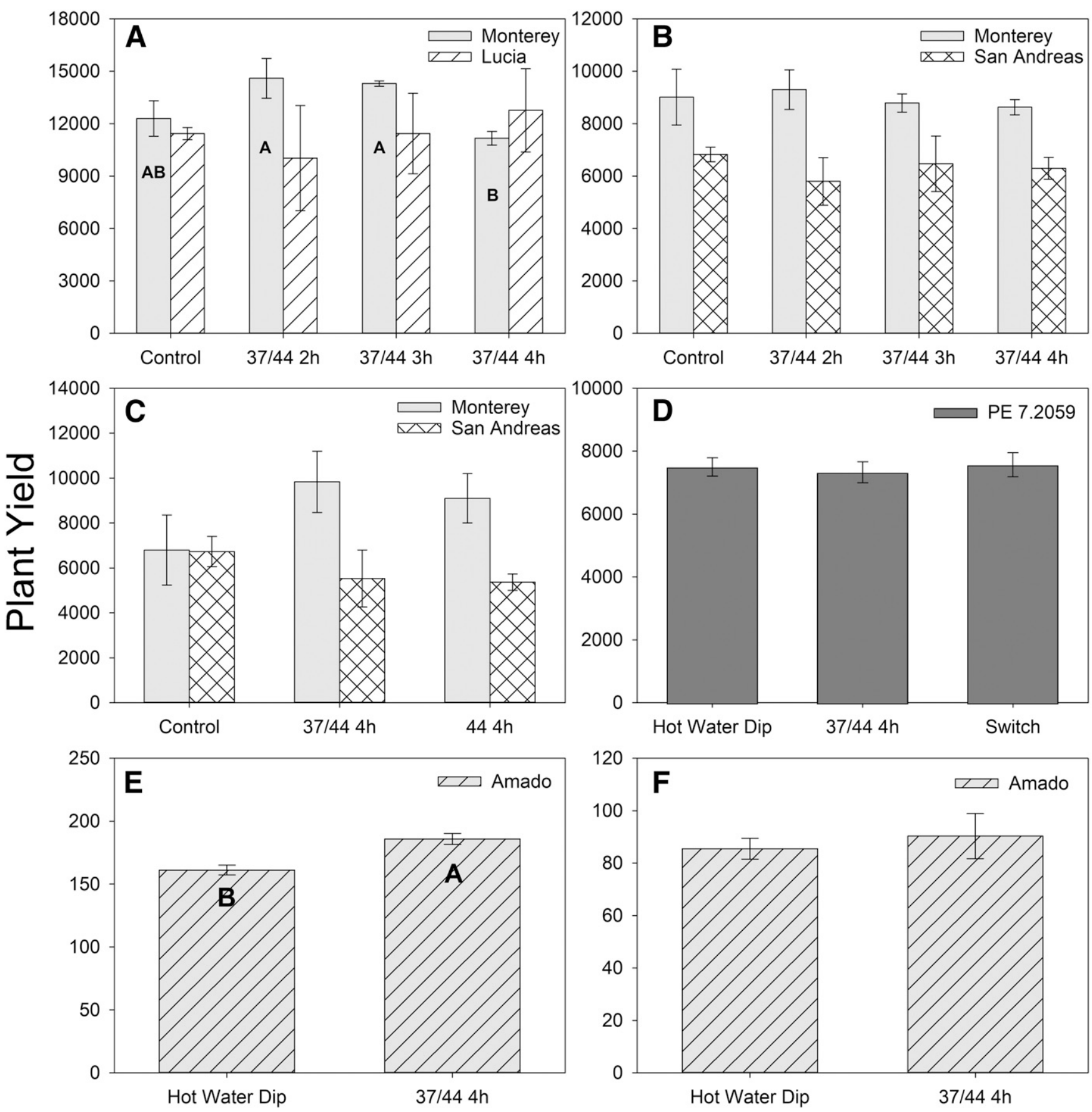

Treatment

FIGURE 11

Plant yields for the low-elevation nursery trials conducted in Manteca, CA, in 2015 (A) and 2016 (B); the high-elevation trial conducted in Macdoel, CA, in 2016 (C); the low-elevation trials conducted in 2017 at Escalon (D) and Ballico, CA (E), and in 2018 at Ballico, CA (F). For the trials $A$ to $D$, full plots were harvested, trimmed, and counted. For trials $E$ and $F$, a subsample of plants were harvested by hand digging all the plants within a $1 \times 1-\mathrm{m}$ wooden frame placed at six evenly spaced locations diagonally across the plot and then summing the six values for a plot-level estimate of yield. Bars represent the average yield and their standard error per treatment and cultivar where applicable. Plant yields were analyzed by cultivar without transformation in a general linear mixed model. Where significant differences occurred, bars that do not share the same letters within a cultivar set are significantly different from each other. 
TABLE 3

Type III tests from linear mixed-model analyses examining the effect of aerated steam treatment (fixed effect) on strawberry nursery plant yields in five trials conducted over 4 years on several cultivars at both high- and low-elevation nursery sites in California

\begin{tabular}{|c|c|c|c|c|c|c|c|}
\hline \multirow[b]{2}{*}{ Trial $^{\mathrm{a}}$} & \multirow[b]{2}{*}{ Year } & \multirow[b]{2}{*}{ Location } & \multirow[b]{2}{*}{ Cultivar } & \multicolumn{4}{|c|}{ Type III tests of fixed effects ${ }^{b}$} \\
\hline & & & & Num $d f$ & Den $d f$ & $F$ value & $\operatorname{Pr}>F$ \\
\hline 1 & 2015 & Manteca & Monterey & 3 & 6 & 4.53 & 0.0551 \\
\hline 1 & 2015 & Manteca & Lucia & 3 & 8 & 0.27 & 0.8443 \\
\hline 2 & 2016 & Macdoel & Monterey & 2 & 4 & 3.15 & 0.1510 \\
\hline 2 & 2016 & Macdoel & San Andreas & 2 & 6 & 0.76 & 0.5096 \\
\hline 3 & 2016 & Manteca & Monterey & 3 & 6 & 0.56 & 0.6621 \\
\hline 3 & 2016 & Manteca & San Andreas & 3 & 6 & 0.70 & 0.5844 \\
\hline 4 & 2017 & Escalon & PE 7.2059 & 2 & 6 & 1.53 & 0.3211 \\
\hline 4 & 2017 & Ballico & Amado & 1 & 3 & 19.55 & 0.0215 \\
\hline 5 & 2018 & Ballico & Amado & 1 & 6 & 0.26 & 0.6297 \\
\hline
\end{tabular}

${ }^{\mathrm{a}}$ In trials 1, 2, and 3, two cultivars were tested at each location. In trial 4, two cultivars at two locations were tested.

${ }^{\mathrm{b}}$ Numerator (Num) and denominator (Den) degrees of freedom ( $\left.d f\right)$, the $F$ statistic $(F)$, and its associated probability $(\operatorname{Pr}>F)$ for each trial and cultivar combination examining the use of aerated steam treatments on plant yields.
PTU performance. The temperature profile within the PTU chamber (six sensors) and within each tray of plants (six trays) is shown in Figure 14 . During the $37^{\circ} \mathrm{C}$ conditioning treatment, all but two of the sensors, both in Amado trays, reached the target temperature of $37^{\circ} \mathrm{C}$. As with earlier trials, the thermostat was set above $37^{\circ} \mathrm{C}$ initially to quickly raise the temperature of the PTU and plants to $37^{\circ} \mathrm{C}$ and then set back to $37^{\circ} \mathrm{C}$ as the temperature in the trays approached the target temperature. Although some of the trays did not reach the target temperature, the temperature that they were exposed to $\left(\sim 30\right.$ to $\left.35^{\circ} \mathrm{C}\right)$ was likely sufficient to induce a heat-shock response. In applying the eradicative treatment, it took $\sim 70$ min for all sensors within trays to reach the target temperature of $44^{\circ} \mathrm{C}$. There was about $1 \mathrm{~h}$, between $12: 30$ and 1:30 p.m., during which the temperature drifted above $44^{\circ} \mathrm{C}$ up to $\sim 47^{\circ} \mathrm{C}$ and then back down to the target temperature, after which it then remained stable.

Plant health and yield. At the midseason ratings in Escalon (numbered selection PE 7.2059), there were no significant differences in plant health among the treatments, with average ratings of $1.33,1.33$, and 1.67 for the PTU-treated, hot-waterdipped, and fungicide-dipped plants, respectively (Table 2; Fig. 10D). Similarly, there were no significant differences in plant

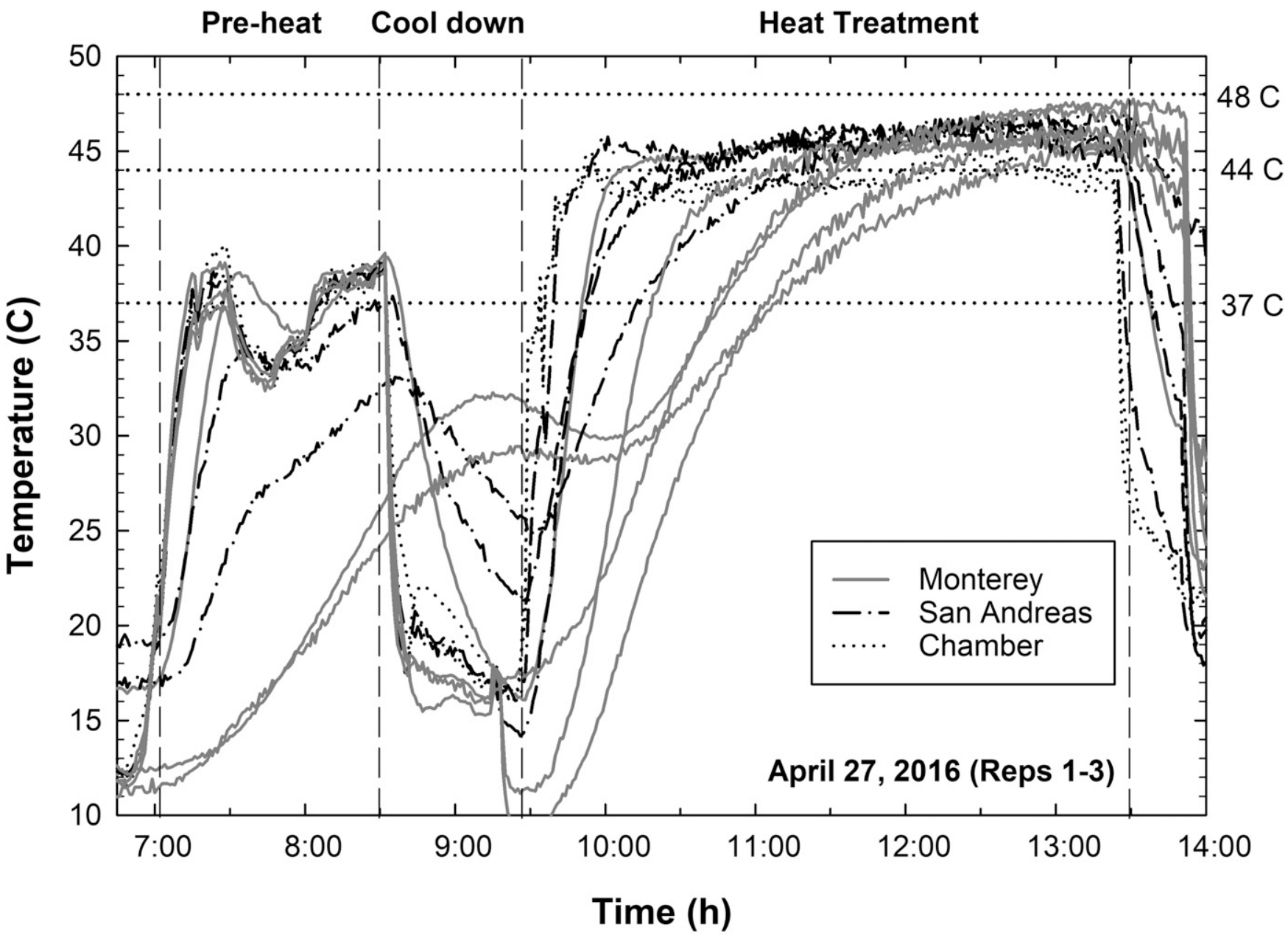

FIGURE 12

Temperature profile of the large precision thermotherapy unit and packaged strawberry boxes for the 2016 high-elevation nursery trial. Thermocouples were buried half-way deep in a subset of boxes at a single location in the middle of six boxes of 'Monterey' (solid lines) and four boxes of 'San Andreas' (dashed-dotted lines). Two thermocouples were used to monitor the interior temperature of the precision thermotherapy unit (dotted lines). 
health among the treatments at Ballico (Amado) with average ratings of 2.0 and 1.75 for PTU-treated and hot-water-dipped plants, respectively (Table 2; Fig. 10E). At harvest, there was no significant difference in yield among treatments from plots harvested at Escalon (Table 3; Fig. 11D). There were, however, significantly more plants harvested from the PTU-treated than hot-watered-dipped plots at Ballico (Table 3; Fig. 11E).

\section{Grower-run trial}

For the grower-run trial conducted in Ballico, CA, the grower applied the thermotherapy protocol as developed with conditioning, cool-down, and eradicative phases. They reported (but did not record) that the target temperatures were achieved. Plants were monitored during the growing season and, at midseason, no obvious differences among treatments were reported (Table 2; Fig. 10F). At harvest, ALS was observed at significantly higher levels in hot-water-treated plots than the PTU-treated plots (Table 4; Fig. 13B). Yields were slightly higher in the PTUtreated plots, although they were not significantly different from the hot-water dipped plots (Table 3; Fig. 11F).

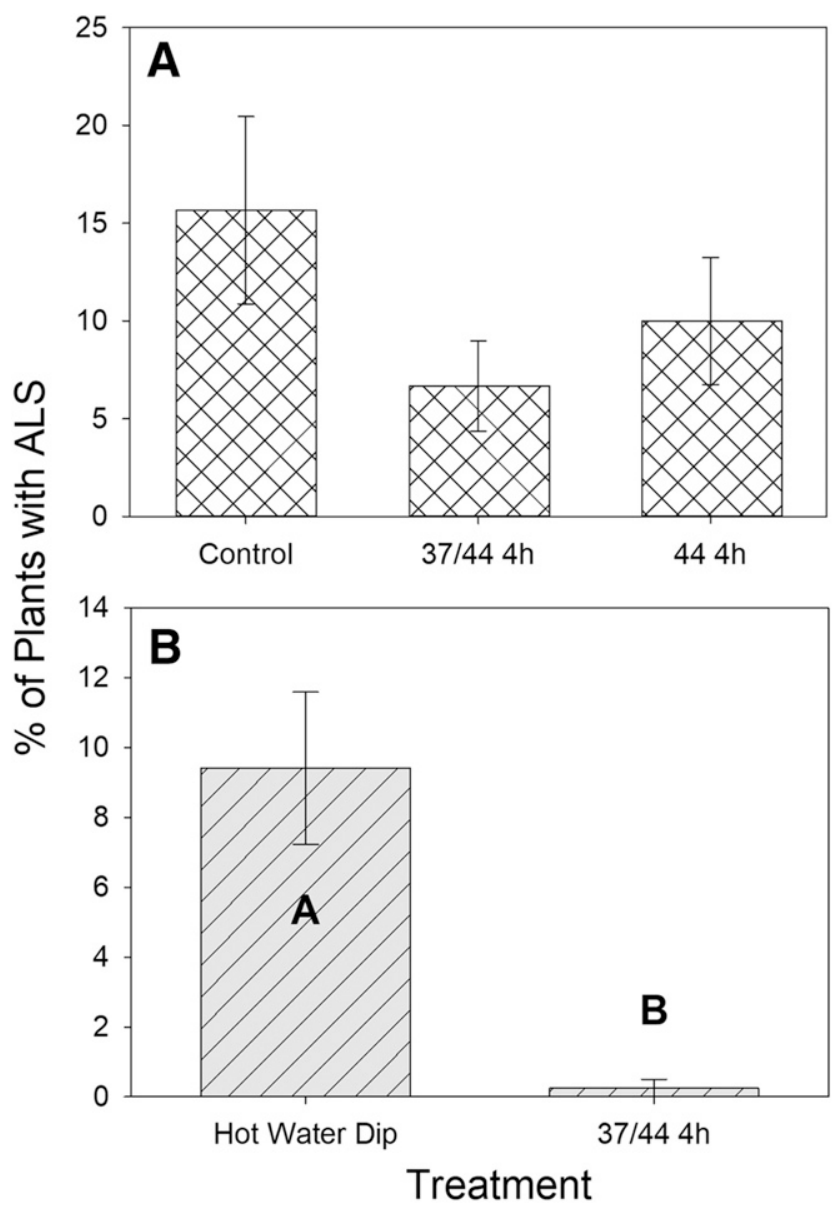

FIGURE 13

Angular leaf spot (ALS) ratings at harvest for the 2016 high-elevation trial in Macdoel, CA (A), and the 2017 low-elevation trial planted in Ballico, CA (B). At Macdoel, each plot was rated at 10 evenly spaced locations across the beds by arbitrarily selecting 10 leaves at each stop and rating them for the presence or absence of symptoms of ALS. At Ballico, disease data were assessed by nursery personnel by estimating the length of row in each plot affected and then calculating the number of mother plants in the affected portion. Where significant differences occurred, bars that do not share the same letter are significantly different.

\section{DISCUSSION}

The precision thermotherapy protocol developed and used here proved to be an effective and safe method for delivering heat (as aerated steam) to strawberry nursery stock. Contaminated nursery stock is the primary source of initial inoculum for ALS in strawberry production fields. Thus, treating nursery stock just prior to planting targets the pathogen when and where it is likely to be at its lowest density, and heat treatment has been shown to be effective at reducing $X$. fragariae populations when applied at this stage (Turechek and Peres 2009). Conversely, no currently registered chemical has proven to be consistently effective at reducing ALS when applied to nursery stock, or for that matter, to production fields (Haack et al. 2019; Mertely et al. 2016, 2017, 2018). The majority of bactericides registered on strawberry are contact chemicals with limited systemic activity that must make direct contact with the bacteria to be effective. Practically, this is challenging because $X$. fragariae resides protected under the epidermis in petiole and crown tissues (Wang et al. 2018). Heat, on the other hand, is penetrative and has known lethal and/or physiological inactivating effects on bacteria (Russell 2003). Turechek and Peres (2009) demonstrated the thermal response of $X$. fragariae to heat and subsequent development of ALS. Here, we expanded on this research and developed a new procedure by combining a new conditioning thermal treatment with a known eradicative treatment. The new protocol was equally effective against ALS but was vastly improved by its ability to reduce adverse effects on plant health and yield typically associated with thermal treatment. Additionally, we built and demonstrated two PTUs as examples of commercial units for delivering this technology safely to large numbers of plants for managing ALS - and potentially other pests and diseases.

Although once a popular method, only a few nursery growers now routinely use hot-water treatment for managing pests and diseases. Many nurseries have been hesitant to adopt thermal treatment (as hot water or steam) as a standard treatment for fear that the treatment will delay growth, stunt/kill plants, and/or spread pathogens such as X. fragariae (Buchner 1991; Turechek and Peres 2009). The use of aerated steam eliminates the concern of bacterial or pathogen spread in bath water, because there is none. The concern of plant stunting/death was addressed with a modification to the original $44^{\circ} \mathrm{C} / 4 \mathrm{~h}$ thermal treatment introduced by Turechek and Peres (2009) by including a conditioning treatment (i.e., $37^{\circ} \mathrm{C}$ for $1 \mathrm{~h}$ followed by 1 -h cool-down at ambient temperature). The conditioning treatment is believed to protect plants exposed to the microbial-lethal $44^{\circ} \mathrm{C} / 4 \mathrm{~h}$ eradicative treatment through the induction of heat-shock proteins (Brown et al. 2016). Precisely applying the conditioning treatment to commercially boxed plants, however, proved challenging. Factors such as the packing density, the cleanliness of

\section{TABLE 4}

Type III tests from linear mixed-model analyses examining the effect of aerated steam treatment (fixed effect) on angular leaf spot of strawberry in five trials conducted over 4 years on several cultivars at both high- and low-elevation nursery sites in California

\begin{tabular}{lccccccc}
\hline & & & & \multicolumn{3}{c}{ Type III tests of fixed effects ${ }^{\mathrm{a}}$} \\
\cline { 5 - 8 } Trial & Year & Location & Cultivar & Num $d f$ & Den $d f$ & $F$ value & $\operatorname{Pr}>F$ \\
\hline 2 & 2016 & Macdoel & San Andreas & 2 & 4 & 2.26 & 0.2207 \\
5 & 2018 & Ballico & Amado & 1 & 6 & 39.07 & 0.0008 \\
\hline
\end{tabular}

a Numerator (Num) and denominator (Den) degrees of freedom $(d f)$, the $F$ statistic $(F)$, and its associated probability $(\operatorname{Pr}>F)$ for each trial and cultivar combination. 
the nursery stock, and the temperature of the nursery stock at the beginning of treatment were all factors that made it difficult to uniformly and quickly heat plants at an even rate. Initially setting the temperature of the PTU above $37^{\circ} \mathrm{C}$ to generate a greater volume of aerated steam was a simple approach to overcome the slow and uneven heating, but it risked damaging the plants should the temperature remain too high for too long. However, under the best of circumstances, it took nearly $1 \mathrm{~h}$ for a "conditioned" box of plants to reach $44^{\circ} \mathrm{C}$ in the PTU, so it seemed unlikely that the plants were in danger of being damaged when we raised the temperature to over $37^{\circ} \mathrm{C}$ during the conditioning phase. In their CATT system, van Kruistum et al. (2015) showed plants exposed to $40^{\circ} \mathrm{C}$ up to $28 \mathrm{~h}$ experienced only minor damage. Given the unavoidable and inherent variability in plant packaging and the associated difficulties in precisely regulating the ramp-up to $37^{\circ} \mathrm{C}$, it is perhaps best to consider $37^{\circ} \mathrm{C}$ as a minimum temperature to achieve the desired heat-shock response and simply redefine the conditioning treatment to a range between 37 and $42^{\circ} \mathrm{C}$ for $1 \mathrm{~h}$ given the thermal "cushion". The heat-shock response should not be affected, because others have shown that exposure to elevated temperatures for as little as 15 min was sufficient for heat-shock protein production (Weng and Nguyen 1992).

There is generally less room for error at the temperature extremes. In nearly all trials, obtaining and maintaining $44^{\circ} \mathrm{C}$ was achieved without having to raise the temperature far above the target temperature. Unlike the conditioning treatment, boxes of plants entering the eradicative treatment phase have been "conditioned" and start the treatment with a homogenous temperature profile. Conditioned plants seemed to achieve their target temperature at a quicker and more uniform rate. Although the protocol is written that plants be exposed to $44^{\circ} \mathrm{C}$ for $4 \mathrm{~h}$, in practice the PTU is set to run for $4 \mathrm{~h}$ at $44^{\circ} \mathrm{C}$. In this case, plants packed on the top of the box or bin will quickly reach the PTU chamber temperature, whereas plants in the middle of the box or bin take approximately $1 \mathrm{~h}$ to reach the $44^{\circ} \mathrm{C}$ target temperature. As with the conditioning treatment, external factors associated with packing and storage affect the rate of heating. In both cases, the addition of a vacuum helped to uniformly apply and increase the rate of heating, although it adds an element that can make it difficult to control heating. During the high-elevation trial, in which four vacuums were used and 18 boxes of plants were treated at once, temperatures reached nearly $48^{\circ} \mathrm{C}$ during the eradicative treatment cycle in our attempt to achieve a stable $44^{\circ} \mathrm{C}$. This could partially explain the stunting observed in the midseason ratings of San Andreas. As stated above, we believe the steam generator was unable to replace the aerated steam quickly enough to maintain a constant temperature when four vacuums were operating. Adding too many vacuums was simply

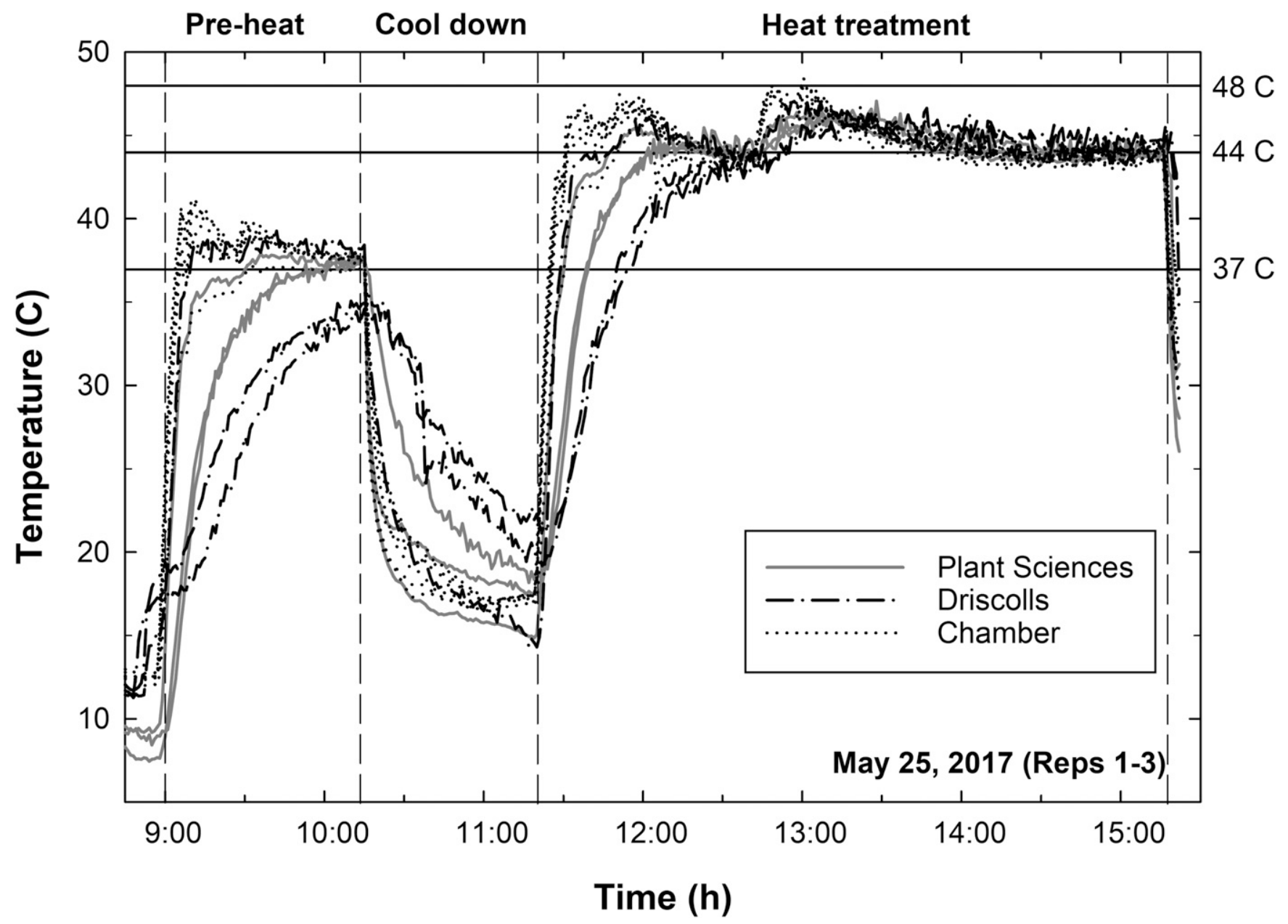

FIGURE 14

Temperature profile within the chamber of the precision thermotherapy unit and of the strawberry plants placed in bins, two to four layers deep, for the 2017 low elevation nursery trial. Three thermocouples were partitioned between the two groups of plants, and individual thermocouples were laid between the layers of plants in the middle of their bins. Three bins of 'PE 7.2059' (solid lines; Plant Sciences) and three bins of 'Amado' (dashed-dotted lines; Driscoll's) were monitored. Six thermocouples were used to monitor the inside chamber temperature of the precision thermotherapy unit (dotted lines). 
an engineering miscalculation, because the PTU functions as intended with the use of one or two vacuums. By using a shipping container, the intent was to have the capacity to treat up to 100 boxes in any single treatment, and clearly more than two vacuums would be needed to reach this goal. The current design cannot accommodate such a demand; however, our collaborators have since designed and built prototypes of PTUs capable of treating approximately 50 boxes of 1,000 plants each.

Despite proven efficacy in our small-plot trials conducted in Fort Pierce and past research (Turechek and Peres 2009), persuading commercial growers to adopt precision thermotherapy in commercial settings has been difficult. There are several explanations for this. First, even if the risk is very low, growers have understandably a natural aversion to any treatment that might kill or stunt plants or reduce yields. Second, most growers want proof that any new treatment will work under their production settings, but they are often reluctant to volunteer the appropriate nontreated control plots often needed to demonstrate efficacy. Considering the specifics of our commercial trials, it is complicated, if not impossible, to design an experiment with known levels of inoculum (i.e., numbers of naturally infected plants), because $X$. fragariae resides asymptomatically on nursery stock, making it difficult to know a priori which plants harbor the pathogen. In addition, no commercial nursery operator would willingly run an experiment with known infected plants or a nontreated control adjacent to their commercial production. Unless nursery stock originated from a planting knowingly infected by $X$. fragariae, which growers avoid, the incidence of infection in nursery stock is often low. Moreover, because incidence is expected to be low, large plots/plantings are typically needed to capture disease when it occurs to demonstrate treatment effect. Most growers do not have or lease extra land to run side experiments, so any trial invariably must be conducted within their commercial plantings. The compromise that we reached was that the thermal treatment was to be included as an additional treatment to target ALS and for growers to continue with their standard disease and pest management practices. ALS has proven recalcitrant to the current arsenal of chemical sprays, and we were confident that within our compromise their standard practices should not mask the effect of thermal treatment.

Although ALS is a problematic disease, it occurs only sporadically and often at low incidences in California's lowelevation nursery plantings. However, ALS can be particularly troublesome in high-elevation plantings where the climate tends to be more favorable for disease development, and these plantings are often the final step in propagation before plants are sent to fruiting fields (i.e., $X$. fragariae accumulates in the planting stock with each step in the propagation chain). Indeed, the high-elevation planting in our experiment was one of two in which ALS appeared in commercial production. Unfortunately, the frequency of scouting prevented us from detecting disease until just before harvest. Also, because plots were only two rows wide and $3 \mathrm{~m}$ apart in the high-elevation trial, interplot interference likely occurred and affected results. In rating the plots, ALS was more prominent at one end of the planting and seemingly originated from the adjacent control plot(s) with noticeably high disease incidence. But because rating was done only at midseason, when ALS was not observed, and then again at harvest 16 weeks later, enough time elapsed for disease to cross plots, likely masking the efficacy of heat treatment. In the growerrun trial, ALS occurred at a high incidence in the hot-waterdipped treatment, whereas the PTU treatments had very low incidence. This not only emphasized the (known) hazards of hotwater dipping and demonstrated the efficacy of precision thermotherapy but also provided evidence that the procedure could be independently replicated in the hands of others.
In anticipating positive feedback from growers, it was important to demonstrate the construction and operation of the PTU and to provide a model or "blueprint" that they could use to construct their own PTU. The smaller PTU built for these trials has been copied by at least two grower groups on the East Coast of the United States and has performed well. In these two instances, growers chose to build a unit in which it is necessary to unpack plants from their boxes and place them in bins for treatment (such as in the Fort Pierce trials and in runs 4 and 5 in the commercial trials). This is a very good option for small- to medium-sized nurseries whose planting strategies can accommodate the unpacking of boxes. For larger nurseries on the West Coast of the United States, the desire is to treat plants while packed in their boxes. This was the motivation for adding vacuum assistance for heating plants. Modifications to the current PTU design to accommodate West Coast production practices are underway and show great promise.

Strawberry nurseries ship plants throughout the United States and the world, and they try to follow the best practices to produce quality, disease-free, and pest-free plants. But even with the best practices, cryptic infections can occur. Should these undetected infections travel with and ultimately lead to a severe epidemic at their destinations, it is often the nursery whose reputation is tarnished and who bears the cost burden. The application of thermal treatment to reduce $X$. fragariae is one way to combat cryptic infections at the nursery level that will translate to a reduction of ALS to where plants are shipped. Beyond ALS, there is evidence of cryptic infection by $C$. acutatum, B. cinerea, and $P$. aphanis (Forcelini and Peres 2018; Oliveira et al. 2017; Silva et al. 2019). To prevent these problems, strawberry nurseries rely heavily on the use of fungicides. But these same fungicides are used widely in fruit production fields, and the selection of fungicide-resistant strains is prominent at both the fruit production and nursery level (Forcelini and Peres 2018; Oliveira et al. 2017). Precision thermotherapy is immune to the impact of fungicide resistance and could be an excellent tool in management of fungicide resistance. Successfully scaling up of the precision thermotherapy process to commercial levels could have an unprecedented impact on controlling diseases while simultaneously reducing fungicide use against a broad range of threats to sustainable production.

\section{ACKNOWLEDGMENTS}

The authors thank Liz Ponce, Scott Scholer, Alfred Ramirez, Jami Simmons, Lee Meier, and Joe Rovito at Lassen Canyon Nursery for giving us the opportunity and allowing us to first test precision thermotherapy. We thank Jenny Broome and Melody Meyer-Jertberg at Driscoll's, Eva Gomez at Sierra-Cascade Nursery, and Mike Nelson, Lenin Ovando, and John Giaimo of Plant Sciences for helping us to advance our work to the next level. We thank Christopher Winterbottom for insights, discussions, and statistics of the strawberry industry. We thank Robert Martin for his technical assistance in troubleshooting the many problems we encountered along the way.

\section{LITERATURE CITED}

Brown, R., Wang, H., Slovin, J., and Turechek, W. W. 2016. The effects of heat treatment on the gene expression of several heat shock protein genes in two cultivars of strawberry. Int. J Fruit Sci. 16(Sup1):239-248.

Buchner, R. P. 1991. Hot water preplant dip for strawberry disease control. Pages 217-218 in: The Strawberry into the 21st Century, A. Dale and J. L. Luby, eds. Timber Press, Portland, OR.

Burr, T. J., Ophel, K., Katz, B. H., and Kerr, A. 1989. Effect of hot water treatment on systemic Agrobacterium tumefaciens biovar 3 in dormant grape cuttings. Plant Dis. 73:242-245.

European Plant Protection Organization (EPPO). 2012. Hot water treatment of strawberry plants to control Aphelenchoides besseyi and Aphelenchoides fragariae. Bull. OEPP/EPPO Bull. 42:493-495. 
Forcelini, B. B., and Peres, N. A. 2018. Widespread resistance of QoI fungicides to Colletotrichum acutatum from strawberry nurseries and production fields. Plant Health Progr. 19:338-341.

Gigot, C., Turechek, W., and McRoberts, N. 2017. Analysis of the spatial pattern of strawberry angular leaf spot in California nursery production. Phytopathology 107:1243-1255.

Gotoh, T., Kitashima, Y., and Sato, T. 2013. Effect of hot-water treatment on the two-spotted spider mite, Tetranychus urticae, and its predator, Neoseiulus californicus (Acari: Tetranychidae, Phytoseiidae). Int. J. Acarol. 39:533-537.

Gramaje, D., Maňas, F., Lerma, M. L., Muňoz, R. M., Garcia-Jimenéz, J., and Armengol, J. 2014. Effect of hot-water treatment on grapevine viability, yield components and composition of must. Aust. J. Grape Wine Res. 20: 144-148.

Haack, S. E., Walse, S. S., Nguyen, K., and Adaskaveg, J. E. 2019. Management of Xanthomonas fragariae with pre- and postharvest treatments to overcome trade barriers for California strawberries. Plant Dis. 103:1256-1263.

Hall, T. W., Heidenreich, M. C., Cicciarelli, R., Andersen, R. L., and Turechek, W. W. 2002. Eradication of Pseudomonas syringae pv. syringae from sweet cherry budsticks. Phytopathology 92:S33.

Herder, K. and Turechek, W. W. 2006. Evaluating hot-water treatment as means for eradicating Xanthomonas fragariae in strawberry nursery stock. Phytopathology 96:S47.

Hoffman, M. T., Doud, M. S., Williams, L., Zhang, M.-Q., Ding, F., Stover, E., Hall, D., Zhang, S., Jones, L., Gooch, M., Fleites, L., Dixon, W., Gabriel, D., and Duan, Y.-P. 2013. Heat treatment eliminates 'Candidatus Liberibacter asiaticus' from infected citrus trees under controlled conditions. Phytopathology 103:15-22.

Keck, M., Chartier, R., Zislavsky, W., Lecomte, P., and Paulin, J. P. 1995. Heat treatment of plant propagation material for the control of fire blight. Plant Pathol. 44:124-129.

Kunkel, L. O. 1936. Heat treatment for the control of yellows and other virus diseases of peach. Phytopathology 26:809-830.

Lewis Ivey, M. L., and Miller, S. A. 2005. Evaluation of hot water seed treatment for the control of bacterial leaf spot and bacterial canker on fresh market and processing tomatoes. Acta Hortic. 695:197-204.

Mertely, J., Cordova, L., and Peres, N.A. 2018. Evaluation of products for management of angular leaf spot in annual strawberry, 2017-18. Plant Dis. Manage. Rep. 12:PF086.

Mertely, J., Martin, R., and Peres, N. A. 2016. Evaluation of products for the control of angular leaf spot in annual strawberry, 2015-16. Plant Dis. Manage. Rep. 10:SMF038.

Mertely, J., Martin, R., and Peres, N. A. 2017. Evaluation of products for controlling angular leaf spot in annual strawberry, 2016-17. Plant Dis. Manage. Rep. 11:SMF026.

Oliveira, M. S., Amiri, A., Zuniga, A. I., and Peres, N. A. 2017. Sources of primary inoculum of Botrytis cinerea and their impact on fungicide resistance development in commercial strawberry fields. Plant Dis. 101: 1761-1768.

Pisetta, M., Albertin, I., Petriccione, M., and Scortichini, M. 2016. Effects of hot water treatment to control Xanthomonas arboricola pv. corylina on hazelnut (Corylus avellane L.) propagative material. Scientia Hortic. 211: 187-193.

Renkema, J., Dubona, F., Peres, N. A. and Evans, B. 2019. Twospotted spider mites (Tetranychus urticae) on strawberry (Fragaria $\times$ ananassa) transplants, and the potential to eliminate them with steam treatment. Int. J. Fruit Sci. 20(Sup1):978-991.

Russell, A. D. 2003. Lethal effects of heat on bacterial physiology and structure. Sci. Progr. 86:115-137.

Silva, C. D., Jr., Hong Le, V., Asalf, B., Grieu, C., Wang, N -Y., Peres, N. A, Turechek, W. W., and Stensvand, A. 2019. Aerated steam by the 'Plant Sauna' eradicates powdery mildew from strawberry transplants. (Abstr.) Phytopathology 109:S2.69.

Turechek, W. W., Hartung, J. S., and McCallister, J. 2008. Development and optimization of a real time detection assay for Xanthomonas fragariae in strawberry crown tissue with receiver operating characteristic (ROC) curve analysis. Phytopathology 98:359-368.

Turechek, W. W., and Peres, N. A. 2009. Heat treatment effects on strawberry plant survival and angular leaf spot, caused by Xanthomonas fragariae, in nursery production. Plant Dis. 93:299-308.

Turechek, W. W., Wang, S., Tiwari, G., and Peres, N. 2013. Investigating alternative strategies for managing bacterial angular leaf spot in strawberry nursery production. Int. J. Fruit Sci. 13:234-245.

van Kruistum, G., Evenhuis, A., Hoek, J., Kastelein, P., van der Wolf, J. M. and Verschoor, J. A. 2015. CATT: A new and non-chemical pest and nematode control method in strawberry planting stock. Acta Hortic. 1105: 189-196.

Wang, H., McTavish, C., and Turechek, W. W. 2018. Colonization and movement of Xanthomonas fragariae in strawberry tissues. Phytopathology 108:681-690.

Wang, H., and Turechek, W. W. 2018. Survival of Xanthomonas fragariae on common materials found in strawberry nurseries. Phytopathology 108: S1.201.

Wang, H., and Turechek, W. W. 2020. Detection of viable Xanthomonas fragariae cells in strawberry using propidium monoazide and longamplicon quantitative PCR. Plant Dis. 104:1105-1112.

Wang, N-Y., Turechek, W. W., and Peres, N. A. 2017. Heat treatment as an alternative to fungicide application for control of strawberry anthracnose caused by Colletotrichum acutatum. Phytopathology 107:S5.50.

Weng, J., and Nguyen, H. T. 1992. Differences in the heat-shock response between thermotolerant and thermosusceptible cultivars of hexaploid wheat. Theor Appl. Genet. 84:941-946.

Zuniga, A., and Peres, N. A. 2017. Heat treatment for management of Botrytis cinerea inoculum on strawberry. Phytopathology 107:S5.49. 